\title{
INWENTARZ KSIEGGZBIORU BISKUPA DIECEZJI LUBELSKIEJ MATEUSZA WOJAKOWSKIEGO (1775-1845) W ŚWIETLE AKT NOTARIALNYCH
}

\begin{abstract}
Streszczenie
W artykule zaprezentowany został inwentarz księgozbioru należącego do biskupa diecezji lubelskiej Mateusza Wojakowskiego (1775-1845). Celem artykułu jest rekonstrukcja księgozbioru, tj. udostępnienie edycji inwentarza odbiorcom wraz ze wstępną analizą zawartości biblioteki. Inwentarz księgozbioru znajduje się w księdze notarialnej z 1845 r., wchodzącej w skład zespołu „Akta Serafina Konwickiego notariusza miasta Lublina” przechowywanego w Archiwum Państwowym w Lublinie. W tekście źródłowym zastosowane zostały zasady edycji zgodnie z Instrukcja wydawnicza dla źródet historycznych od $X V I$ do XIX wieku. Ponadto uzupełniono i wzbogacono dane bibliograficzne, ponieważ źródłowe informacje dotyczące posiadanych przez duchownego egzemplarzy książek były niepełne, gdyż pierwotnie służyły jedynie dla celów spadkowych. Ustalonopełny tytuł, nazwiskoautora, miejsce, rokwydaniawoparciu o dostępne bibliografie i katalogi biblioteczne. Poczynione ustalenia pozwolą na pełniejszą analizę zawartości domowej biblioteki biskupa. W inwentarzu liczącym 220 pozycji wymieniono łącznie 255 tytułów dzieł w 296 woluminach. Gromadzone książki były przede wszystkim w języku polskim, ponadto po łacinie, w języku francuskim i niemieckim. Domowy księgozbiór duchownego miał uniwersalny charakter. Zawierał książki i czasopisma z różnych dziedzin: ogólne, prawne, o edukacji, filozoficzne, z historii, geografii, słowniki, z nauk przyrodniczych i stosowanych, literaturę piękną. Ważną część stanowiły druki religijne, w tym księgi liturgiczne, kazania, katechizmy, modlitewniki, Biblia, rozmyślania. Inwentarz księgozbioru biskupa Wojakowskie-
\end{abstract}

* Anna Dymmel - dr hab. historii, Instytut Nauk o Kulturze, Uniwersytet Marii Curie-Skłodowskiej w Lublinie

e-mail: annadymmel@wp.pl

https://orcid.org/0000-0003-3532-3590 
go - postaci wyróżniającej się nie tylko na polu działalności duszpasterskiej, ale i obywatelskiej - nie był dotychczas znany i wykorzystywany w literaturze. Jest to także przykład inwentarza XIX-wiecznego księgozbioru należącego do duchownego.

Słowa kluczowe: księgozbiór; biskup Mateusz Wojakowski; duchowieństwo; akta notarialne; inwentarz; XIX wiek

$* * * * *$

Mateusz Maurycy Wojakowski herbu Brochwicz urodził się 13 września 1775 r. we wsi Chechły na Mazowszu, w rodzinie drobnoszlacheckiej Kaspra i Gertrudy z Lipskich. Po ukończeniu gimnazjum benedyktyńskiego w Pułtusku wstąpił do tamtejszego seminarium duchownego i następnie w 1796 r., przyjął święcenia kapłańskie. Przez osiem lat zarządzał parafią w Kuklinie, jednak ze względów rodzinnych przeniósł się w 1804 r. do Lublina i wkrótce objął probostwo w Garbowie. W nowym miejscu dał się poznać ze swej działalności na niwie kościelnej i w niedługim czasie, bo w 1809 r., został kanonikiem honorowym kapituły lubelskiej, a od 1812 r. pełnił funkcję sędziego surogata przy konsystorzu lubelskim. W $1824 \mathrm{r}$. otrzymał nominację apostolską na biskupa tytularnego Arcadiopolis. Jego aktywność zwróciła uwagę ordynariusza lubelskiego Wojciecha Skarszewskiego. W rezultacie, po otrzymaniu nominacji na biskupstwo kaliskie przez dotychczasowego sufragana diecezji lubelskiej Józefa Koźmiana, M.M. Wojakowski został konsekrowany na biskupa i sufragana lubelskiego w 1825 r. ${ }^{1}$ Jednocześnie, zgodnie z wymogami stawianymi kandydatom na biskupa, uzyskał honorowy doktorat Uniwersytetu Krakowskiego nadany 23 września 1824 r., jako że duchowny „odznaczał się biegłością w świętej teologii”. Mateusz Wojakowski miał też liczne zasługi na polu służby obywatelskiej, m.in. pełnił urząd sędziego pokoju w powiecie lubartowskim, był członkiem Towarzystwa Gospodarczo-Rolniczego w Lublinie i wizytatorem szkół województwa lubelskiego. Ponadto, zapewne w dowód docenienia jego aktywności i zasług, trzykrotnie został wybrany deputowanym na sejm Królestwa Polskiego $(1818,1820,1825)$. Duchowny zabiegał też o założenie szkoły elementarnej w Garbowie dla ubogiej młodzieży, ale wskutek braku finansowego wsparcia nie udało się zrealizować tego zamiaru. W czasie powstania listopadowego ogłosił list wzywający wiernych do walki, za co został aresztowany $\mathrm{i}$ - mimo podejmowanych starań - zesłany w głąb Rosji do twierdzy Bobrujsk. Zwolniony z przymusowego pobytu w marcu 1834 r. z uwagi na stan zdrowia powrócił do Lublina, ale swoje obowiązki sufragana podjął dopiero w $1835 \mathrm{r}$. W 1839 r. kapituła powierzyła mu zarząd diecezją lubelską, a papież mianował administratorem apostolskim diecezji lubelskiej². Biskup M.M. Wojakowski zmarł 2 lutego 1845 r. i został pochowany

${ }^{1}$ Biblioteka Wojewódzka im. H. Łopacińskiego w Lublinie. Papiery po biskupie Lubelskim Wojakowskim, sygn. 515, Rks r.1802, 1843, Opis życia, k. 33-34; J.K. Wasilewski, Poczet biskupów lubelskich, http://www.bu.kul.pl/art_11485.html (dostęp: 01.12.2019); P. Nitecki, Biskupi kościoła w Polsce w latach 965-1999. Stownik biograficzny, Warszawa 2000, szp. 487-488.

${ }^{2}$ I. Sadurski, Biskup sufragan lubelski Mateusz Maurycy Wojakowski wobec powstania listopadowego, w: Powstanie Listopadowe na Lubelszczyźnie. Wydarzenia, ludzie, źródła, red. A. Barańska, J. Skarbek, Lublin-Oświęcim 2013, s. 54-76; J. Skarbek, Udziat duchowieństwa lubelskiego 
w krypcie starego kościoła pw. św. Wojciecha w Garbowie. W 2010 r., dzięki staraniom ówczesnego proboszcza, szczątki biskupa zostały odnalezione i następnie wmurowane w ścianę kościoła. Fakt ten upamiętnia tablica poświęcona przez abpa Józefa Życińskiego w dniu 6 listopada 2010 r. $^{3}$

Celem artykułu jest przede wszystkim rekonstrukcja księgozbioru biskupa M.M. Wojakowskiego na podstawie inwentarza pośmiertnego. Nie był on dotychczas przedmiotem zainteresowania, tymczasem stanowi ciekawe źródło do badań stosunkowo słabiej rozpoznanych XIX-wiecznych bibliotek prywatnych duchowieństwa. Inwentarze księgozbiorów, niezależnie od niedoskonałości, są niewątpliwie przydatnym źródłem poszerzającym wiedzę o kulturze książki oraz kulturze umysłowej środowiska i jednostki, co nabiera szczególnego znaczenia wobec oddziaływania duchowieństwa na świadomość oraz postawy społeczeństwa w epoce zaborów ${ }^{4}$. Należy dodać, że niniejsze dociekania uzupełniają wciąż nie do końca rozpoznany obszar badań nad księgozbiorami domowymi na Lubelszczyźnie w XIX wieku ${ }^{5}$.

Inwentarz ruchomości po biskupie M.M. Wojakowskim zachował się w jednym z tomów wchodzących w skład obszernego zespołu „Notariusze miasta Lublina" przechowywanego w Archiwum Państwowym w Lublinie 6 . Akt spisany w kancelarii ziemiańskiej notariusza Serafina Konwickiego (1797-1859) ${ }^{7}$ znajduje się w księdze zawierającej akta notarialne sporządzone we wspomnianej kancelarii w 1845 r. Stan zachowania księgi jest dobry. Inwentarz z racji objętości został oddzielony od pozostałych aktów stroną zawierającą tytuł dokumentu. Obejmuje on łącznie 50 kart, z czego 15 zajmują 2 wykazy: „książek rozmaitych” i ,książek duchownych". Dokument został spisany dość czytelnym pismem, zawiera nieliczne skreślenia, a sporządzenie jego całości trwało od 10 marca do 6 czerwca 1845 r. Sam akt ma formę właściwą dla tego typu dokumentów. Biskup M.M. Wojakowski nie sporządził testamentu, dlatego pozostałości przypadły ustawowo najbliższej rodzinie, po odliczeniu części należnej kościołowi. Do grona spadkobierców należeli: siostra Honorata z Wojakowskich Zembrzuska zamieszkała we wsi

w Powstaniu Listopadowym, „Roczniki Humanistyczne”, 17 (1969) z. 2, s. 83-93; J. Ziółek, Patriotyczna postawa duchowieństwa w czasie powstania 1830-1831 roku, „Roczniki Humanistyczne”, 28 (1980) z. 2, s. 79-103.

${ }^{3}$ H. Stępniak, Spotkanie naukowe „Biskup sufragan lubelski Mateusz M. Wojakowski w powstaniu 1830-1831", 20.11.2012, https://garbow.pl/aktualnosci/n,62428,spotkanie-naukowe-biskup-sufragan-lubelski-mateusz-m-wojakowski-w-powstaniu-1830-1831.html (dostęp: 01.12.2019).

${ }^{4}$ A. Dymmel, Lubelskie akta notarialne jako źródła do badań prywatnych księgozbiorów duchowieństwa w pierwszej połowie XIX wieku, „Archiwa, Biblioteki i Muzea Kościelne”, 110 (2018) s. 145-166, https://doi.org/10.31743/abmk.2018.110.09 (dostęp: 01.12.2019).

${ }^{5} \mathrm{~A}$. Dymmel, Ksiegozbiory prywatne ziemiaństwa lubelskiego w połowie XIX wieku (w świetle akt notarialnych Serafina Konwickiego), „Res Historica”, 13 (2002) s. 243-255; J. Kozińska-Chachaj, Księgozbiory ziemiańskie na Lubelszczyźnie w XIX i XX w., „Bibliotekarz Lubelski”, 47 (2004) s. 61-74.

${ }^{6}$ Archiwum Państwowe w Lublinie (dalej: APL), Akta Serafina Konwickiego notariusza w Lublinie, 1845, akt 634 (43).

${ }^{7}$ R. Gerber, Studenci Uniwersytetu Warszawskiego 1808-1831. Stownik Biograficzny, Wrocław 1977, s. 97; S. O[strołęcki], Cmentarz parafialny rzymsko-katolicki w Lublinie, Warszawa 1902, s. 13. 
Garbów $^{8}$ w okręgu lubartowskim, reprezentowana podczas spisania inwentarza przez kontrolera kasy powiatu lubelskiego Tomasza Gliszczyńskiego, oraz dzieci nieżyjącego brata Ignacego. W ten sposób stosowne udziały przypadły obecnym $\mathrm{w}$ trakcie spisywania aktu bratankom, tj. Michałowi Wojakowskiemu ze wsi Biel ${ }^{9}$ położonej $\mathrm{w}$ okręgu ostrołęckim $\mathrm{w}$ województwie płockim (przemianowanym w 1837 r. na gubernię) i Andrzejowi Wojakowskiemu zamieszkałemu we wsi Pogorzelce ${ }^{10} \mathrm{w}$ okręgu (powiecie) stanisławowskim. Ponadto należne części przysługiwały nieobecnym przy spisywaniu aktu pozostałym bratankom, tj. Józefowi Napoleonowi Wojakowskiemu ze wsi Sokolniki ${ }^{11}$ położonej w powiecie opoczyńskim (ówcześnie należącym do guberni radomskiej), Wojciechowi Wojakowskiemu będącemu w wojsku rosyjskim oraz bratanicy Ludwice z Wojakowskich Skorulskiej zamieszkałej w Irenie ${ }^{12}$ w powiecie zamojskim, żonie Napoleona Skorulskiego urzędnika przy fabryce wyrobów żelaznych. Nieobecnych reprezentował rejent Engelbert Kozłowski ${ }^{13}$, natomiast wyceny pozostałości dokonali powołani biegli: jubiler Fryderyk Kren i stolarz Józef Ostrowski. Przy spisaniu inwentarza obecny był także ksiądz Wincenty Nowakowski, poddziekan dekanatu kazimierskiego i proboszcz parafii markuszowskiej upoważniony do odebrania inwentarza fundi instructi, ponadto asesor powiatu lubelskiego Szymon Ladachowski reprezentujący prawa probostwa Garbów oraz dwaj świadkowie. Po uzupełnieniach poczynionych na wniosek Honoraty Zembrzuskiej i Michała Wojakowskiego domagających się wpisania do inwentarza rzeczy znajdujących się w domu w Lublinie, notariusz sporządził wykaz pozostawionego majątku. Akt rozpoczynają wiadomości wstępne typowe dla dokumentu notarialnego, tj. data, miejsce, wymienienie stawiających się stron. Następnie notariusz dokonał spisu majątku należącego do biskupa, obejmującego nieruchomości i mobilia pozostawione w dobrach w Garbowie oraz w mieszkaniu w Lublinie pod nr 109 (Grodzka 13). Zgodnie z wymogami urzędowymi zastosowana została podwójna datacja, natomiast wyliczane dobra zostały pogrupowane w 48 kategorii, tzw. tytułów. Na pierwszym miejscu notariusz wymienił nieruchomości, gotowe pieniądze, kosztowności (w tym sre-

\footnotetext{
${ }^{8}$ Garbów, wieś i folwark, parafia, powiat puławski (nowoaleksandryjski). Stownik geograficzny Królestwa Polskiego i innych krajów słowiańskich, nakł. Filip Sulimierski i Władysław Walewski, Warszawa 1880-1914, t. 2, s. 484.

${ }^{9}$ Biel, wieś, woj. płockie, pow. ostrołęcki. Tabella Miast, Wsi, Osad Królestwa Polskiego z wyrażeniem ich położenia i ludności alfabetycznie ułożona w Biórze Kommisji Spraw Wewnętrznych i Policyi, Warszawa 1827, t. 1, s. 26.

${ }^{10}$ Pogorzelce, wieś, woj. mazowieckie, pow. stanisławowski. Tabella Miast, Wsi, Osad Królestwa Polskiego z wyrażeniem, t. 2, s. 106.

${ }^{11}$ Sokolniki, wieś, woj. sandomierskie, pow. opoczyński. Tabella Miast, Wsi, Osad Królestwa Polskiego z wyrażeniem, t. 2, s. 192; Sokolniki, wieś i folwark, pow. radomski. Słownik geograficzny Królestwa Polskiego, t. 11, s. 21.

${ }^{12}$ Irena, wieś i osada fabryczna nad rzeką Sanną, pow. janowski, gmina Zaklików, znajdowała się tu m.in. walcownia żelaza i fabryka maszyn rolniczych zał. przez Henryka Łubieńskiego, od 1843 r. własność Banku Polskiego, zatrud. ok. 120 robotników. Słownik geograficzny Królestwa Polskiego, t. 3 , s. 300 .

${ }^{13}$ Ur. ok. 1799-1855, notariusz kancelarii ziemiańskiej w Lublinie, http://www.sejm-wielki.pl/ b/sw.164165 (dostęp: 01.12.2019).
} 
bro, srebro kościelne, kosztowności własne), następnie naczynia z nowego srebra, mosiądz, cynę i blachę, zegary, lustra, obrazy, w dalszej kolejności sprzęty drewniane, aparaty i naczynia kościelne oraz własne, futra, garderobę i narzędzia ogrodowe. Wykaz dóbr spisany został w formie tabeli zawierającej rubryki: numer bieżący, przedmiot wraz z szacunkową kwotą wyrażoną słownie i liczbowo. Pod tytułem oznaczonym numerem XXXX wyliczone zostały „książki rozmaite”, kolejna część inwentarza (oznaczona XXXXI) zawierała spis „książek duchownych”.

Opis egzemplarza książki w źródle tworzonym dla celów spadkowych daleki jest od dokładności bibliograficznej znanej z katalogów bibliotecznych. Spisujący posługiwał się zazwyczaj tytułem dzieła, niejednokrotnie skróconym, sporadycznie wymieniał nazwisko autora, w większości przypadków brakuje roku wydania, nie podawał miejsca edycji, natomiast znalazły się uwagi o stanie zachowania, oprawach i szacunkowa wycena.

Księgozbiór liczył łącznie 220 pozycji, z czego 187 zostało zaliczonych przez spisującego do działu „książki rozmaite”, natomiast 33 druki zakwalifikowano jako „książki duchowne”. Trzeba dodać, że część mniejszych objętościowo dzieł, głównie z literatury pięknej, była współoprawna, co powiększa księgozbiór o 35 pozycji wydawniczych, zatem liczył on 255 tytułów w 296 woluminach.

Zmierzając do charakterystyki księgozbioru, należy rozpocząć od cech formalnych. W biblioteczce przeważały druki zwarte, niemniej w 24 przypadkach odnotowano periodyki stanowiące źródło bieżącej informacji, ale też zawierające poważniejsze treści. Księgozbiór był urozmaicony pod względem języka publikacji, niemniej daje się zauważyć przewagę druków w języku polskim - 208 tytułów $(81,88 \%)$, ale występowały także książki po łacinie - $31(12,20 \%)$, w języku francuskim - $13(5,11 \%)$ i po niemiecku - 3 druki.

Ważny element charakterystyki biblioteki stanowi analiza struktury tematycznej pozwalająca stwierdzić, jakie książki trafiły do prywatnego księgozbioru duchownego. W świetle inwentarza tematyka księgozbioru biskupa M.M. Wojakowskiego przedstawiała się następująco. Opracowania z różnych dziedzin stanowiły połowę zebranej biblioteczki $(50 \%)$, w tym opracowania ogólne - 34 tytuły $(15,38 \%)$. Składały się nań głównie czasopisma - 24 pozycje, ponadto kalendarze i zbiory dzieł. Wśród periodyków zasadniczą część stanowiły XIX-wieczne czasopisma warszawskie poświęcone różnorodnej tematyce, głównie literaturze, nauce, gospodarstwu, polityce i zdrowiu. Wśród nich znalazły się roczniki „Rozmaitości Warszawskich” z lat 1821-1838 stanowiące dodatek do „Gazety Korrespondenta Warszawskiego", zawierające początkowo ciekawostki, z czasem wzbogacone o utwory literackie i artykuły informacyjno-naukowe. Teksty z literatury pięknej publikowano w dodatku do Gazety Warszawskiej „Tęcza” (1838-1839) i stanowiącym jego kontynuację dodatku „Wieniec” (1839-1840). Ponadto w bibliotece znajdował się początkowy tom znanego oświeceniowego czasopisma „Izys Polska czyli Dziennik Umiejętności, Wynalazków, Kunsztów i Rękodzieł, Poświęcony Kraiowemu Przemysłowi, Tudzież Potrzebie Wieyskiego i Mieyskiego Gospodarstwa” z 1820 r., a także tom „Dziennika Zdrowia” uznawanego za pierwsze polskie czasopismo lekarskie, wydawanego w latach 1801-1802. W księgozbiorze nie zabrakło kwartalnika pt. „Dziennik Gospodarczo-Rolniczy” będącego orga- 
nem Towarzystwa Królewskiego Rolniczego i skupionego na tematyce gospodarstwa wiejskiego. Zbiór czasopism uzupełniał „Rocznik Wojskowy” z 1817 r. oraz tom „Rocznika Instytutów Religijnych i Edukacyjnych” (1824-1830), na łamach którego omawiano zagadnienia pedagogiczne. W spisie biblioteki widniały także wciąż popularne kalendarze, które dzięki nowoczesnej formule nie przypominały krytykowanych przez oświeceniową prasę prognostyków wcześniejszej epoki. Poza niezbędną chronologią zawierały urozmaicone treści, stanowiąc źródło wiedzy i rozrywki. W księgozbiorze zachował się m.in. Kalendarzyk kieszonkowy warszawski z 1833 r. i kalendarze polityczne z ostatnich lat: 1843 i 1844 r.

Ponadto w bibliotece należy wyróżnić książki z następujących dziedzin: filozofii - $15(6,81 \%)$, religii - 17 (8,18\%), nauk społecznych - 26 (11,81\%), a wśród nich: prawne -14 , o edukacji -5 , ekonomii -4 , polityce -2 , wojskowości -1 . W mniejszych proporcjach występowały opracowania z nauk ścisłych i przyrodniczych $-2(0,90 \%)$ i z nauk stosowanych $-5(2,28 \%)$, w tym poruszające kwestie techniki i gospodarstwa -2 oraz z medycyny -3 . W dalszej kolejności należy wymienić książki o literaturze, języku i wymowie - $10(4,5 \%)$, z historii - $12(5,45 \%)$ i geografii - 6 (2,72\%), trudne do zakwalifikowania pozostają 3 tytuły. Znaczą część księgozbioru stanowiła urozmaicona gatunkowo literatura piękna - 91 (41,36\%). Ponadto w oddzielnym spisie wymienione zostały 33 tytuły $(15,06 \%)$,książek duchownych", wśród których znajdowały się przede wszystkim dzieła teologiczne, druki liturgiczne, inne wydawnictwa przydatne w pracy duszpasterskiej.

Dość znaczny zestaw dzieł filozoficznych składał się z wybranych dzieł starożytnych, z których trzeba odnotować jedno z wydań traktatu Lucjusza Anneusza Seneki $O$ krótkości życia i dzieło Cicerona De officis. W bibliotece duchownego nie zabrakło aktualnych rozpraw współczesnych myślicieli epoki oświecenia. Aczkolwiek wiek filozofów przyniósł rozkwit formacji kulturowej odwołującej się do siły rozumu, niemniej koniec XVIII stulecia był także okresem rewolucyjnych zmian, głównie we Francji, godzących m.in. w ustalony porządek i z założenia mających antykościelny charakter. W rezultacie w opozycji do encyklopedystów rozwinął się nurt antyoświecenia przestrzegający przed upadkiem moralnym, chaosem i postępującą laicyzacją, broniący zasad katolicyzmu ${ }^{14}$. W bibliotece biskupa znajdowała się polemiczna w swym charakterze praca pijara uznawanego za jednego z prekursorów polskiego oświecenia Antoniego Wiśniewskiego Rozmowa filozoficzna o Boskich procz Jestności Przymiotach Przeciw niegodziwie sobie przywłaszczającym nazwisko Deistów (Warszawa 1758). W domowym księgozbiorze znalazło się także dzieło napisane w obronie wiary katolickiej pt. Helwianki czyli listy prowincjonalno-filozoficzne autorstwa znanego przeciwnika rewolucyjnych zmian Augustina Barruela, w tłumaczeniu reformata Karola Surowieckiego, wydane w Warszawie w 1819 r. ${ }^{15}$ Należy dodać, że w zbiorze można zauważyć inne polemiczne pisma reformata i chociaż niekiedy tworzone w kon-

${ }^{14}$ R. Szczurowski, Oświecenie i kontroświecenie czasów Królestwa Polskiego. Polemika o. Karola Surowieckiego z ministrem Stanisławem Kostka Potockim, „Folia Historica Cracoviensia”, 23 (2017) nr 2, s. 406-426.

${ }_{15}$ J. Bazydło, Barruel Augustin, w: Encyklopedia katolicka, t. 2, red. F. Gryglewicz, R. Łukaszyk, Z. Sułowski, Lublin 1995, kol. 64. 
wencji literackiej, miały na celu przede wszystkim krytykę przeciwników katolicyzmu. Dobry przykład tego typu twórczości stanowiła tragedia Python Lipsko-warszawski Diabet kontrtragedia opozycyjna wobec utworu Saul wyszydzającego postaci biblijne. Wśród „ksiąg rozmaitych” znajdowały się ponadto Rzecz o jezuitach, polemiczne wobec religii protestanckiej Listy doktora Akademii Strazburskiej i List bytego Pastora w Conde do swoich wspótwyznawców. Do biblioteki M.M. Wojakowskiego trafiło cieszące się poczytnością dzieło francuskiego historyka kościoła Claude'a Fleury'ego Zbiór historii ludu izraelskiego y uwag nad nim politycznych $z$ Xiag Pisma świętego ${ }^{16}$. Ważne miejsce w domowym zbiorze zajmowały liczne francuskojęzyczne edycje kazań i zbiory dzieł francuskiego królewskiego duszpasterza biskupa Jean-Bapiste Massillon.

Ponadto należy wspomnieć książkę włoskiego teologa i arcybiskupa Giovanniego Marchettiego Cudowny schyłek osiemnastego wieku, w thumaczeniu Karola Surowieckiego. Nie zabrakło opisu życia hiszpańskiego założyciela i pierwszego generała pijarów św. Józefa Kalasantego (José de Calasanz) Zebranie życia S-go Józefa Kalasantego. Zestaw uzupełniały: katechizm Pierwiastki religii katolickiej ks. Grzegorza Wężyka wydany w Lublinie oraz podejmujące sprawy duchowości Obowiązki damy chrześcijańskiej, ponadto zbiór pieśni i Żywot Pana Jezusa.

$\mathrm{Na}$ opracowania z nauk społecznych składały się przede wszystkim druki prawne, wśród których przeważały kodeksy z czasów przynależności Lublina do zaboru austriackiego, w obrębie którego znalazło się miasto po III rozbiorze. Były to wydania ustaw cywilnych dla Galicji zachodniej po łacinie, tj. Codex civilis pro Galicia occidentali (Viaenne 1797) i w języku polskim Ustawa cywilna dla Galicyi zachodniey (Wiedeń 1797), austriacki kodeks prawa karnego Księga ustaw na zbrodnie i stosowne skorowidze. W domowym zbiorze znajdowały się także ogólniejsze opracowania, m.in. wykład doktryny prawa naturalnego (Krótkie zebranie Trzech Praw Początkowych. To jest: Prawa Natury, politycznego i Narodów z różnych Autorów wyięte) oraz rozprawa Wacława Aleksandra Maciejowskiego wprowadzająca w założenia prawa rzymskiego.

Do księgozbioru trafiły ponadto opracowania adresowane do czytelników zainteresowanych problematyką nauczania i szkolnictwa, w tym Nouveaux essais d'education Olivera Goldsmitha przełożony z języka angielskiego. Sprawom edukacji w duchu katolickim poświęcony był traktat Edukacya katolicka iest najwyższym dobrem kraiu. Trzeba także wymienić rozprawę G. Wężyka prezentującego organizację szkoły gorzkowskiej i stosowane metody nauczania, powstałą w odpowiedzi na dyskusje nad kierunkiem rozwoju oświaty w Królestwie Polskim i kształtem szkolnictwa elementarnego na Lubelszczyźnie, toczone w ramach Lubelskiego Towarzystwa Przyjaciół Nauk ${ }^{17}$. Ten ostatni problem był przedmiotem szczególnej troski Lubelskiego Towarzystwa z uwagi na nikłą sieć placówek poziomu elementarnego w województwie. Nie zabrakło przy tym w domowej bi-

${ }^{16}$ B. Modzelewska, W. Wójcik, Fleury Claude, w: Encyklopedia katolicka, t. 5, red. L. Bieńkowski i in., Lublin 1989, kol. 324-325.

${ }^{17}$ A. Winiarz, Szkolnictwo Księstwa Warszawskiego i Królestwa Polskiego (1807-1831), Lublin 2012, s. 122. 
bliotece broszury pióra profesora Szkoły Wojewódzkiej Lubelskiej Witalisa Witkowskiego poddającego krytycznej ocenie propozycje G. Wężyka ${ }^{18}$.

Ponadto warto wymienić druki poruszające zagadnienia ekonomiczne i polityczne, w tym rozprawę Monteskiusza i dotyczący aktualnych zagadnień Krótki rzut oka na teraźniejszy stan kraiu z 1820 r. Zainteresowanie, jak można przypuszczać, wzbudziła broszura Projekt polepszenia stanu włościan nieznanego autora. Ponadto nie zabrakło wydawnictw skupiających się na problemach ekonomicznych dotyczących kościoła, w tym broszury Uwagi nad uwagami o dziesięcinach, której twórca podjął dyskusję z poglądami Tadeusza Czackiego sformułowanymi w rozprawce $O$ dziesięcinach rzecz czytana na posiedzeniu Towarzystwa Warszawskiego Przyjaciót Nauk.

W bibliotece nielicznie występowały opracowania z nauk ścisłych i przyrodniczych, reprezentowane przez jedno $\mathrm{z}$ wydań dzieła znanego francuskiego naturalisty Julien-Josepha Virey'a Historia obyczajów i instynktu zwierząt (I wyd. Warszawa 1828, II wyd. Warszawa 1844). Prawdopodobnie użyteczną rolę spełniały opracowania z nauk stosowanych. Przede wszystkim przydatne okazały się poradniki z zakresu techniki i gospodarstwa, praktycznie ukazujące zasady budownictwa wiejskiego (P. Świtkowski, Budowanie wiejskie) oraz poradniki medyczne zawierające zalecenia służące zachowaniu zdrowia i wskazówki postępowania w przypadku chorób. W domowej bibliotece znajdowało się będące ówcześnie w powszechnym użyciu vademecum szwajcarskiego popularyzatora wiedzy medycznej Szymona A. Tissota Porządek życia w czerstwości oraz podręcznik poświęcony położnictwu. Uwagę właściciela księgozbioru zwrócił także druk autorstwa nadwornego lekarza Stanisława Augusta Poniatowskiego Jana Nepomucena Hermanna Opusculum impedimenta quedam sanitatis communia dotyczący stanu sanitarnego m.in. Lublina, wydany w drukarni Trynitarzy w Lublinie.

W księgozbiorze można znaleźć ponadto podręczniki retoryki, o literaturze i gramatyki. Zachowały się m.in. podręczniki Rhetorica Institutio i De arte Rhetorica, szkolne wydawnictwa Tirocinum Lingue latinae, bliżej nieokreślona gramatyka łacińska i do nauki języka niemieckiego.

Podobnie jak w wielu innych prywatnych bibliotekach epoki w zbiorze duchownego nie zabrakło opracowań historycznych, w tym wykładu Luciusa Florusa O poczatku i dzieiach Narodu Rzymskiego i czterotomowej Historii jakobinizти Augustina Barruel przełożonej z języka francuskiego. Z czasem księgozbiór został uzupełniony o cieszący się popularnością Rękopism nadesłany z wyspy św. Heleny, a następnie książkę autorstwa Tomasza Dziekońskiego Życie marszatków francuskich. Nie zabrakło popularnego herbarza Piotra Nałęcz Małachowskiego Zbiór nazwisk szlachty z opisem herbów wydanego w Lublinie w 1805 r. W księgozbiorze występowały ponadto opracowania poświęcone geografii, zarówno podręczniki końca XVIII wieku, jak i nowoczesne kompendia powstałe w kolejnych dziesięcioleciach następnego stulecia, czego dobry przykład stanowiło opracowanie Obraz świata pod względem geografii, statystyki, $i$ historyi wszystkich

${ }^{18}$ Z. Kukulski, Towarzystwo Przyjaciót Nauk w Lublinie na tle epoki (1815-1830), Lublin 1939, s. LXXIV. 
krajów T. Dziekońskiego. Ponadto można zauważyć druki poświęcone opisowi poszczególnych państw, tj. Opis Egiptu Fr. Celestyna Chasseboeuf Volney, Opisanie Królestwa Portugalii Auberta R. Vertot.

Znaczną część zbioru stanowiła literatura piękna, na co złożyło się 91 wymienionych publikacji (ponad $41 \%$ ). Były to przede wszystkim utwory dramatyczne (31 tytułów), częściej komediowe, komedioopera, ponadto licznie występowały powieści (26 tytułów), zarówno końca XVIII wieku, jak i modne romanse XIX wie$\mathrm{ku}$, następnie poezje, poematy, listy, zbiory dzieł. Były to niejednokrotnie przekłady z literatury francuskiej, niemieckiej, angielskiej, ale nie brakowało dzieł polskich autorów. W tym urozmaiconym zestawie trzeba wyliczyć XVIII-wieczne przekłady tragedii Jeana Racina dokonane na potrzeby teatrów warszawskich, dramaty Moliera i Jean-François Marmontela. Literaturę obcą reprezentowały również utwory francuskiego dramaturga i powieściopisarza Jean-Pierre Clarisa Floriana, ponadto obecne były modne utwory sceniczne dramaturga niemieckiego Fryderyka Augusta Kotzebue. Wśród utworów prozatorskich znalazł się polski przekład angielskiej powieści Jonathana Swifta Podróże kapitana Guliwera. Nie zabrakło XIX-wiecznych powieści Waltera Scotta, Charlesa Cocka i innych ówczesnych bestsellerów wydawniczych, np. Piotra Knigge Idzi Blas czyli przypadki Piotra Klaus. Wśród poezji znajdowało się francuskojęzyczne wydanie Les odes Pierre'a de Ronsard.

Do biblioteki trafiły także utwory rodzimych autorów, w tym Ignacego Krasickiego (m.in. Dzieła, Bajki), ponadto trzeba wymienić utwory sceniczne ułożone przez dyrektora Teatru Narodowego Ludwika A. Dmuszewskiego oraz aktora i dramatopisarza Alojzego G. Żółkowskiego. Zbiory zasiliły Poezje Franciszka Kniaźnina, utwór Wincentego Gawareckiego Oblężenie Płocka rycerskie drama, ponadto prace literackie Juliana Ursyna Niemcewicza. Dopełnienie stanowiły zbiory i serie np. Czytania zabawne, czyli wybor przygód, powieści moralnych $i$ anekdotów z różnych autorów z końca XVIII wieku oraz Gabinet czytania wydawany przez Franciszka Salezego Dmochowskiego w latach 1834-1835.

W skład księgozbioru wchodziły także spisane pod oddzielnym tytułem „książki duchowne". Wśród 33 pozycji $(15,06 \%)$ wymienione zostały przede wszystkim dzieła teologiczne, w tym wykłady teologii moralnej, dogmatycznej, rozmyślania, ponadto druki liturgiczne, kazania, katechizmy, modlitewniki i Biblia ${ }^{19}$.

Nie zabrakło wykładów m.in. jezuity i kardynała Roberta Bellarmina Pietnaście stopni po których czlowiek, zwłaszcza krześciański, upatrujac Pana Boga $w$ stworzeniu rozmaitym, przychodzi do wielkiey znajomości iego. Księgozbiór zawierał również polski przekład popularnego w Europie scholastycznego wykładu dogmatów religii katolickiej Katechizm filozoficzny jezuity Franciszka X. Fellera, uznawanego za prekursora XIX-wiecznego tradycjonalizmu ${ }^{20}$. Do biblioteki trafił znany praktyczny poradnik życia XVI-wiecznego włoskiego duchownego Lorenza Scupoli Woyna duchowna (pierwsze wydanie Wenecja 1589) wielokrotnie przekła-

${ }^{19}$ D. Olszewski, Książka religijna na terenie Królestwa Polskiego w XIX wieku, „,Rocznik Świętokrzyski”, 16 (1989) s. 149.

${ }^{20}$ M. Daniluk, Feller François Xavier, w: Encyklopedia katolicka, t. 5, kol. 112-113. 
dany na liczne języki obce. Odnotowane zostało ponadto dzieło C. Fleury'ego Podziat historyi Swiętey, a także Krótka [nauka] o rozmyślaniu.

Księgozbiór zasiliły dzieła ascetyczne i żywoty świętych, w tym Chwała męczennika świętego Jana Nepomucena oraz Jasna pochodnia albo żywot Świętego Franciszka Salezjusza autorstwa ucznia Wincentego à Paulo i twórcy licznych dzieł teologicznych Ludwika Abelly'ego ${ }^{21}$.

Biblioteka została zaopatrzona $\mathrm{w}$ potrzebne druki liturgiczne przydatne przede wszystkim dla duchowieństwa $\mathrm{z}$ wyższymi święceniami: mszały, zbiory ceremonii, pontyfikały. Niezbędną pomoc w pracy duszpasterskiej stanowiły kazania, w tym Wybór kazań kapucyna Wiatora Piotrowskiego ${ }^{22}$. W domowej biblioteczce nieodzowne były także modlitewniki, w tym książka do nabożeństwa ułożona przez arcybiskupa Marcina Dunin Sulgustowskiego, mająca pierwsze wydanie w 1842 r., która wielokrotnie wznawiana szybko zyskała szczególną popularność na przestrzeni XIX stulecia. Na uwagę zasługuje także Dictionaire Historique, critique, chronologique, géographique et littéral de la Biblie i jedno z wydań Nowego Testamentu Jakuba Wujka.

Jakkolwiek trudno na podstawie inwentarza służącego pierwotnie przede wszystkim ustaleniu stanu posiadania wnioskować wprost o zainteresowaniach czytelniczych właściciela, to jednak można uznać wspomniane źródła za istotne dla badania kultury środowiska w przeszłości ${ }^{23}$. Mimo dylematów interpretacyjnych, urozmaicona i uniwersalna tematyka księgozbioru, przy uwzględnieniu specyfiki potrzeb duchownych, może dobrze wpisywać się w różnorodne zainteresowania właściciela, nie można też wykluczyć szerszego kręgu użytkowników biblioteki. Na pewno jest to interesujący przykład księgozbioru należącego do przedstawiciela wyższego duchowieństwa, przy tym stanowiący własność niewątpliwie nietuzinkowej postaci Kościoła.

Stan zachowania księgozbioru, jak wynika z opisu egzemplarzy, był dobry i dowodził dbałości o bibliotekę. Większość ksiąg została zaopatrzona w oprawy zazwyczaj półskórkowe lub papierowe, nie brakowało jednak woluminów chronionych przez okładki skórzane lub oprawionych w droższy safian, co też podnosiło wartość biblioteki. W efekcie taksatorzy wycenili księgozbiór łącznie na 27 rubli (dalej: rsr) i 32 i 1 1 k2 kopiejki, przy czym wartość druków rozmaitych wynosiła 14 rsr i 34 kopiejki, natomiast dzieła duchowne, zdaniem wyceniających, prezentowały wartość 8 rsr i 95 i 1/2 kopiejki. Taksa pojedynczych tomów okazała się zróżnicowana i wahała się od $1 / 2$ kopiejki do 1 rsr. Powyższe ceny należy uznać za nieco zaniżone, co stanowiło dość powszechną praktykę stosowaną przy spisywaniu inwentarza $\mathrm{z}$ uwagi na przepisy podatkowe. Jednostkowo największą war-

${ }^{21}$ S. Smoleński, Abelly Louis, w: Encyklopedia katolicka, t. 1, red. F. Gryglewicz, R. Łukaszyk, Z. Sułowski, Lublin 1985, kol. 13.

${ }^{22}$ R. Prejs, Piotrowski Wiator, w: Encyklopedia katolicka, t. 15, red. E. Gigilewicz, Lublin 2011, kol. 704.

${ }^{23} \mathrm{~B}$. Bieńkowska, Inwentarze księgozbiorów prywatnych jako źródto do badań nad dziejami czytelnictwa, „Studia o Książce”, 18 (1989) s. 65-75; J. Szady, Inwentarz księgozbiorów parafialnych $z$ drugiej połowy XVIII wieku - nowa metoda edycji, „Textus et Studia”, 1 (2016) nr 5, s. 78-90, doi: 10.19265/TES.2016.01577. 
tość przedstawiały przede wszystkim druki liturgiczne oszacowane po $1 \mathrm{rsr}$, w tym: Canon Misse in folio, Ceremoniale Episcoporum, Pontyfikale Romanum z 1627 r. i XVIII-wieczne edycje Breviarum Romanum oprawione w skórę, niekiedy zaopatrzone w futerał. Z dzieł świeckich wartość 1 rsr osiągnął zestaw 24 tomów czasopisma „Wieniec” w 13 woluminach oprawionych w półskórek, natomiast na 45 kopiejek wyceniona została nowo wydana książka Życie marszatków francuskich zaopatrzona w safianową okładkę.

Brak daty wydania zgromadzonych dzieł, poza pojedynczymi wzmiankami, nie pozwala na jednoznaczne określenie chronologii księgozbioru, niemniej można zauważyć w biblioteczce obecność starych druków. Były to przede wszystkim wspomniane powyżej druki liturgiczne z XVII wieku, ponadto dość licznie występowały XVIII-wieczne edycje, szczególnie pochodzące z drugiej połowy stulecia, jak można domniemywać na podstawie ustaleń bibliograficznych. Jednocześnie, co istotne, trzeba dostrzec nowości wydawnicze sugerujące aktywne zainteresowanie uzupełnianiem domowego księgozbioru o pojawiające się na rynku tytuły. Z pewnością przydatny był Kalendarzyk polityczny z 1844 r., Directorium officis divini na tenże rok, ale obok tych niewątpliwie użytkowych publikacji znalazły się nowości przyciągające uwagę nie tylko treścią, ale i nowoczesną formą edytorską, zaopatrzone w ryciny. Były wśród nich dzieła o tematyce historycznej poświęcone epoce napoleońskiej, utwory literackie, mogące zapewnić czytelnikowi owocną poznawczo i przyjemną lekturę. Podobnie brak adnotacji w inwentarzu o miejscu wydania publikacji nie pozwala na szczegółowe, jednoznaczne stwierdzenia, niemniej w świetle dostępnych danych bibliograficznych można przyjąć, iż wymienione druki pochodziły z różnych ośrodków wydawniczych, głównie krajowych, ale też z oficyn zagranicznych.

Dalsze losy księgozbioru nie są do końca znane. Wiadomo jednak, o czym świadczy notarialny akt licytacji, że został on wraz z pozostałymi ruchomościami, zgodnie z wolą spadkobierców, sprzedany. Księgi trafiły w prywatne ręce, część egzemplarzy zakupili lubelscy księgarze zapewne z myślą o dalszej odsprzedaży.

Rekonstruując księgozbiór, korzystano z Bibliografii polskiej Karola Estreichera, katalogu Biblioteki Narodowej w Warszawie, katalogu Bibliothèque Nationale de France, innych katalogów bibliotek cyfrowych. W przypadku dzieł, dla których z racji niejasności zapisu źródłowego, nie można było dokonać jednoznacznego ustalenia, podawano możliwe przypadki. Ponadto wobec niepełnych danych uniemożliwiających zidentyfikowanie konkretnego wydania wymieniono znane edycje wydane do 1845 r., tj. daty śmierci biskupa M.M. Wojakowskiego, w przypadku wielokrotnych wydań odnotowano liczbę edycji, a dla czasopism lata wydania. Zachowano tytuły podane w źródle w oryginalnej pisowni, wprowadzono nieliczne modernizacje zgodnie z zaleceniami Instrukcji wydawniczej dla źródet historycznych od XVI do połowy XIX wieku (red. K. Lepszy, Wrocław 1953). Zmodernizowano pisownię: półskurek = półskórek, skurzany = skórzany, iedna $=$ jedna, wstawiono znaki diakrytyczne, zachowano pisownię: xiądz, exemplarz, diecezyi, xięgi, siedm. W obrębie wykazu książek zachowano ciągłą numerację stosowaną $\mathrm{w}$ inwentarzu, $\mathrm{w}$ nawiasie kwadratowym został dodany numer porządkowy. 
$* * * * *$

Inwentarz po Xu biskupie [Mateuszu] Wojakowskim ${ }^{24}$

(26 lutego)10 marca 1845

\section{Książki rozmaite}

[k. 1] [1] 1167 Gramatyka niemiecka ${ }^{25}$ część pierwsza w półskórek oprawna zużyta pół kopiejki

[2] 1167 [s] Kasimir Wohlfeils deutsche sprachlehre ${ }^{26}$ w papier oprawne pół kopiejki

[3] 1168 Codex Judiciarius pro Galicia occidentali ${ }^{27}$ W papier oprawny pół kopiejki

[4] 1169 Skorowidz ustaw cywilnych z roku 1797 dla Galicyi ${ }^{28}$ w papier oprawny, pół kopiejki

[5] 1170 Documenta ad causas Decimales in Polonia ${ }^{29} \mathrm{w}$ trzech exemplarzach w papier oprawny kopiejka jedna

[6] 1171 Regulae Iuris ${ }^{30}$ w półskórek oprawne zużyte pół kopiejki

[7] 1172 Codex Civilis pro Galicia Occidentali część pierwsza ${ }^{31}$ w papier oprawny pół kopiejki

[8] 1173 Codex Civilis pro Galicia occidentali część druga ${ }^{32}$ w papier oprawny pół kopiejki

\footnotetext{
${ }^{24}$ APL, Akta Serafina Konwickiego notariusza miasta Lublina 1845, akt 634 (43).

${ }^{25}$ Niemożliwe do jednoznacznego ustalenia. M.in. Grammatyka niemiecka podtug naylepszego czasów terażnieyszych mówienia i pisania sposobu, Sandomierz 1782; Estr., t. 17, s. 328; Franciszek Lieder, Gramatyka niemiecka przez Radę Wychowania publicznego polecona Szkołom i Instytutom naukowych w Królestwie Polskim, nakład autora, Warszwa 1835, wyd. 2 popr., Warszawa 1841; Estr. XIX, s. 598-599.

${ }^{26}$ Kasimir Wohlfeils, Deutsche Sprachlehre, druk. Pillera, Lemberg 1797; K. Estreicher, Bibliografia Polska, Kraków 1870-2000 (dalej: Estr.), t. 22, s. 197; Kasimir Wohlfeils, Deutsche Sprachlehre, Lemberg 1800; Estr., t. 5, s. 129.

${ }^{27}$ Codex judiciarius pro Galicia occidentali, typis Josephi Hraschanzky, Viennae 1797; Codex judiciarius, Viennae 1798; Estr., t. 14, s. 314.

${ }^{28}$ Ludwik Wędrychowski, Skorowidz czyli zbiór alfabetyczny ustaw cywilnych w 3 częściach dla Galicyi w roku 1797 nadanych, ku wygodzie publiczności w rodowitym języku ustaw tych wiadomości potrzebującéj z największa pilnościa ułożony przez Ludwika Wędrychowskiego, kosztem i nakł. Karola B. Pfaffa, Lwów 1800; Estr., t. 5, s. 30.

${ }^{29}$ Józef Olechowski, Documenta ad causas decimales in Polonia (...) Opus impressum Cracoviae in lingua vernacula 1779 nunc vero in Latina luci publicae datum, typis Universitatis, Cracoviae 1798; Estr., t. 23, s. 319.

${ }^{30}$ Stanisław Łochowski, Regulae iuris et loci com̄unes forenses; quorum de jure et praxi communi, tritus et versatus in foro usus, et allegatio. Authore Stanislao Łochowski Castri Opoczneń. Notario (...), officina Francisci Caesarii, Cracoviae 1637; Estr., t. 21, s. 370.

${ }^{31}$ Codex civilis pro Galicia occidentali, typis Josephi Hraszanzky, Caes. Reg, Aulae typogr. Bibliop., Viennae 1797; Estr., t. 14, s. 314.

${ }^{32}$ Toż, Pars II., k. nlb. 2, s. 256; Pars III, k. nlb. 2, s. 259.
} 
[9] 1174 Jeometrya cywilna część pierwsza ${ }^{33}$ w skórę oprawna kopiejka jedna [10] 1175 Ustawa cywilna dla Galicyi zachodniey część pierwsza ${ }^{34}$ w papier oprawna pół kopiejki

[11] 1176 Tirocinum Linguae latinae in usum classis primae ${ }^{35} \mathrm{~W}$ papier oprawne kopiejka jedna

[12] 1177 Tirocinum Linguae latinae pars posterior ${ }^{36} \mathrm{~W}$ półskórek oprawne zużyte pół kopiejki

[13] 1178 Philosofia ad usum scholae accomodata ${ }^{37}$ tom szósty w półskórek oprawny kopiejka jedna

[14] 1179 Rzecz o Jezuitach ${ }^{38} \mathrm{w}$ papier oprawna kopiejka jedna

[15] 1180 Essai d'education Nationale ${ }^{39} \mathrm{w}$ papendecel oprawna kopiejki dwie

[16] $1181 \mathrm{M}$. Tullii Ciceronis Epistolae familiares ${ }^{40} \mathrm{w}$ pergamin oprawne kopiejki trzy

${ }^{33}$ Prawdopodobnie: Ignacy Zaborowski, Jeometrya Praktyczna. przez X. Ignacego Zaborowskiego, druk. XX. Scholarum Piarum, Warszawa 1786. Kolejne wydania: 1792, 1806, 1815, 1820; albo Szymon L'Huillier, Geometrya dla Szkót narodowych, cz. 1-2, druk. Gröll, Warszawa 17801781, 1804, 1810; Szymon L'Huillier, Geometrya [...] drugi raz wydana, cz. 1, druk. Szkoły Główney Koronney, Kraków 1785. Inne wydanie: Wilno 1796; Estr., t. 21, s. 252; Estr., t. 8, ed. 2, s. 321; Ponadto: Geometrya, Estr., t. 17, s. 99.

${ }^{34}$ Ustawy Cywilne Dla Galicyi Zachodniey, cz. 1-3, druk. Józefa Hraszańskiego, C.K. Niemieckiego i Polskiego nadwornego Typografa i Bibliopoli, Wiedeń 1797; Estr., t. 32, s. 94.

${ }^{35}$ Fryderyk Gedike, Tirocinium linguae Latinae in usum classis primae, typis Scholarum Piarum, Varsaviae 1821; Estr. XIX, t. 8, s. 299.

${ }^{36}$ Jedno z wydań: Fryderyk Gedike, Tirocinium linguae latinae in usum I. et II. Classis, druk. XX. Pijarów, Warszawa 1806; Fryderyk Gedike, Tirocinium linguae Latinae, in usum primae et secundae classis. Pars prior, typis PP. Scholarum Piarum, Varsaviae b.r. (1811) 1813. Łącznie ukazało się 9 wydań do $1845 \mathrm{r}$.

${ }^{37}$ Prawdopodobnie: Guillaume Dagoumer, Philosophia ad usum scholae accommodata, nova editio, t. 1-4 Lugduni, sumptibus fratrum Duplain, 1746, https://gallica.bnf.fr/services/engine/search/ sru?operation $=$ searchRetrieve \&version $=1.2 \&$ collapsing $=$ disabled\&rk $=21459 ; 2 \&$ query $=\% 28 \mathrm{dc}$.title\%20all\%20\%22Philosophia\%20ad\%20usum\%20scholae\%20accommodata $\% 22 \% 29 \% 20$ and $\% 20$ dc.relation\%20all\%20\%22cb30294860m\%22 (dostęp:10.11.2019); albo: Louis Loudier, Philosophia ad usum scholae accomodata, data a D. D. Loudier licenciato theologo socio Sorbonico necnon philosophiae professore celeberrimo in collegio Sorbonae Plessaeo, scripta ab auditore Joanne Baptista Castel, clerico Petrogovensi eodem collegio anno Domini expirante 1722-1723, https://nubis. univ-paris1.fr/ark\%3A/15733/1bcf\#?c=0\&m=0\&s=0\&cv=0\&xywh=0\%2C-831\%2C4423\%2C4556 (dostęp: 10.11.2019); albo: Jean Baptiste du Hamel, Philosophia vetus et nova ad usum scholae accommodata, in Regia Burgundia olim pertractata, Tomus primus, qui logicam complectiur, Venetis 1730.

${ }^{38}$ Prawdopodobnie Jezuici w prawdziwey swoiey postaci albo doskonate uwiadomienie o ich dotychczas sprawowaniu się z niemieckiego na polski ięzyk przełożone nakładem pewnego W. N. Prałat, druk. Jan F. Bartels, Gdańsk 1765; Ignacy Krasicki, Jezuici w prawdziwey swoiey postaci, nakład i podobno thum. Ignacy Krasicki, Gdańsk 1765, wyd. 2, Gdańsk 1770; Estr., t. 18, s. 552.

${ }^{39}$ Louis Réné de Caradeuc de La Chalotais, Essai d'éducation nationale, ou, Plan d'études pour la jeunesse, 1763, https://gallica.bnf.fr/ark:/12148/bpt6k854049.image (dostęp: 10.11.2019).

${ }^{40}$ Jedno z wydań m.in.: M.T. Cicero, Epistolae familiares, Gedani 1638; M.T. Cicero, Epistolae familiares, Pauli Manutii annotationes breves in margine adscriptae. Ejusdem scholia. Verba grae- 
[17] 1182 Rok miłości Boskiej ${ }^{41}$ w skóre oprawne kopiejek dwie

[18] 1183 De arte Rhetorica ${ }^{42}$ w skóre oprawna pół kopiejki

[19] 1184 Mowy Sądowe Quintyliana ${ }^{43}$ w papier oprawne kopiejka jedna

[k. 2] [20] 1185 Księga ustaw na zbrodnie ${ }^{44} \mathrm{~W}$ papier oprawna kopiejka jedna [21] 1186 Historya na dwie części podzielona ${ }^{45}$ w papier oprawne kopiejki trzy [22] 1187 Rocznik Wojskowy z roku $1817^{46} \mathrm{~W}$ papier oprawny pół kopiejki [23] 1188 Odpowiedź o pogrzebach wiedeńskich ${ }^{47}$ bez oprawy pół kopiejki

ca latinis expressa. Dionysii Lambini Monstroliensis, viri doctissimi, emandationes, \& earum rationes, Dantisci, typis et sump. Andreae Hünefeldii, bibliopol, 1641; M.T. Cicero, Epistolae familiars, Officina Chr. Schedelii, Cracovae 1643; M.T. Cicero, Epistolae familiares cum Pauli Manutii annotationibus brevibus in margine adscriptis, cum privil. S.R. M. Polon. et Sueciae, sumptibus viduae G. Försteri, Gedani 1663; Estr., t. 14, s. 3.

${ }^{41}$ Jan Chrzciciel Eliasz Avrillon, Rok miłości Boskiey z pieni świętych na każdy dzień roku przez affekta rozłożony, przez Wielebnego Oyca... potrzeciraz (sic!) do druku w roku pańskim 1719 podany, a teraz z francuskiego języka na polski przez zakonnice Nawiedzenia Nayświętszey Maryi Panny klasztoru Krakowskiego przettumaczony, druk. Seminarium biskupiego akademickiego, Kraków 1767; Estr., t. 12, s. 315.

${ }^{42}$ Wydanie trudne do jednoznacznego ustalenia, m.in. ukazały się: Aristotelis de arte rhetorica libri tres, Carolo Sigonio interprete, offiic. Stanislai Scharffenbergii, Cracoviae 1577; Dominico Decolonia, De arte rhetorica libri quinque. Lectissimis veterum auctorum aetatis aureae, perpetuisque exemplis illustrati auctore Dominico de Colonia Societatis Jesu Presbytero, Typis Collegii Soc. Jesu, Lublini 1754, wbp.lublin.pl $/$ dlibra $/$ docmetadata $2 i d=22356 \&$ from $=$ pubindex\&dirids $=22 \& 1 \mathrm{p}=283$ (dostęp: 10.11.2019). Inne wydania: Lublini 1756, Posnaniae 1758, Leopoli 1763,Vilnae 1770, Sandomiriae 1780, Polociae 1788, 1799; albo De Arte rhetorica veterum libri, Lublini 1783; Estr., t. 26, s. 287; albo Piotr X., De arte rhetorica libri quinque lectissimis veterum authorum aetatis aureae exemplis illustrati et ad usum candidatorum eloquentiae accommodati, typis Colleg. Soc. Jesu, Polociae 1799; Estr., t. 12, s. 211-212; lub: Cyprjan Soarez S.J. (Suares), De Arte Rhetorica Libri Tres, Ex Aristotele, Cicerone, Et Qvinctiliano Praecipve Deprompti. Auctore Cypriano Soarez Sacerdote Societatis Jesv. Additae Svnt Tabvlae Rhetorices, Per Lvdovicvm Carbonem Selectae, Dantisci, sump. Georgii Förster, 1645, 1651. Inne wydania: Calissii 1678, 1682, 1685; albo Cypriani Soarii, De Arte Rhetorica Libri Tres, Ex Aristotele, Cicerone, Qvinctiliano, Praecipve deprompti. Huic editioni accedunt Tabulae seu Artis Rhetoricae absolutissimum compendium Lud: Carbonis Constanciario S. Th: Professoris in gymnasio Patavino, Calissii, Typis Collegii Societatis Jes., 1696, 1706 i inne wyd. do 1734; Estr., t. 28, s. 341-342.

${ }^{43}$ Quintilianus M. Fabius, Wybornieysze Mowy Sadowe z Lacińskiego Języka wyttumaczone przez X.B.M. Sirucia S. P. P. A. Xiążka Pierwsza, druk. J.K.M. y Rzpltey XX. Schol. Piar., Wilno 1769 (t. 2, 1771); Estr., t. 25, s. 443.

${ }^{44}$ Jedno z wydań: Księga ustaw na zbrodnie i ciężkie policyjne przestępstwa, druk. J. Trasslera, Kraków 1804; albo Księga ustaw na zbrodnie i ciężkie policyjne przestępstwa, druk. Pillera, cz. 1-2, Lwów 1804. Inne wydania: Lwów 1804, Wiedeń 1817; Estr., t. 2, s. 513, http://www.bibliotekacyfrowa.pl/publication/62574 (dostęp: 10.11.2019).

${ }^{45}$ Tytuł trudny do jednoznacznego ustalenia.

${ }^{46}$ „Rocznik Wojskowy Królestwa Polskiego”, Warszawa 1817-1830; Estr., t. 3, s. 466.

${ }^{47}$ [Odpowiedź] autorowi pisma kilku kartek Lwowskiemu o pogrzebach wideńskich przydatna. Od Erazma y Wideńczyka katolickiego, za dozwoleniem Starszych Zwierzchności wydana, druk. Akademii, Zamość 1781. Odpowiedź na: O pogrzebach Wideńskich pismo małe $w$ Wiedniu roku p. 1781 drukowane z niemieckiego Języka na Polski dla użytku powszechnego za pozwoleniem Zwierzchności przetlumaczone, druk. Kazimierza Schlichtyna J.K. Mci uprzywil. Typ., Lwów (1781); Estr., t. 23, s. 257. 
[24] 1189 Uwagi nad organizacyą szkoły Gorzkowskiej8 bez oprawy pół kopiejki [25] 1190 Proiekt polepszenia stanu włościan ${ }^{49} \mathrm{w}$ papier oprawny pół kopiejki

[26] 1191 Principia Juris Romani ${ }^{50} \mathrm{w}$ papier oprawne kopiejki trzy

[27] 1192 Listy Doktora Akademii Strazburskiej ${ }^{51}$ bez oprawy kopiejki dwie

[28] 1193 Rocznik Instytutow ${ }^{52}$ w papier oprawny kopiejka jedna

[29] 1194 Cudowny schyłek osiemnastego wieku ${ }^{53} \mathrm{w}$ papier oprawny kopiejki trzy

[30] 1195 Selecta Latini Sermonis ${ }^{54}$ tom 1. w papier oprawny kopiejka jedna

[31] 1196 O krotkości życia przez Seneke ${ }^{55}$ w papier oprawne kopiejka jedna

[32] 1197 Zebranie życia S-go Józefa Kalasantego ${ }^{56}$ w papier oprawne pół kopiejki

${ }^{48}$ Witalis Witkowski, Uwagi nad organizacya szkoły gorzkowskiey, Lublin 1821; Estr., t. 5, S. 109 .

${ }^{49}$ Sumiński, Projekt polepszenia stanu włościan podany przez prefekta departamentu płockiego, b.m., b.r.; Estr. XIX, t. 4, s. 410.

${ }^{50}$ Wacław Aleksander Maciejowski, Historia juris romani, t. 1: Principiorum juris romani, Varsaviae 1825; Estr. XIX, t. 3, s. 31.

${ }^{51}$ [Alexander Brodowski X.], Listy pewnego Doktora Akademii Strażburskiey Katolickiej do iednego szlachcica protestanta. O sześciu przeszkodach do zbawienia znajdujacych się $w$ religii luterskiej, z francuzkiego na polski język przettumaczone przez ..., S. J. Theologa, druk. Akademick. S. J., Lwów 1761; Estr., t. 13, s. 353.

52 „Rocznik Instytutów Religijnych i Edukacyjnych w Królestwie Polskim”, Warszawa 18241830; Estr., t. 3, s. 464.

${ }^{53}$ Giovanni Marchetti, Cudowny schyłek osiemnastego wieku czyli Niestychane widoki, które w roku 1796 i 1797 podobało się Bogu przedstawić ludzkim oczom w rzymskich i za-rzymskich, szczególniey Nayświętszy Matki Jezusowey, obrazach, tł. Karol Surowiecki, Wrocław 1814; Estr. XIX, t. 4, s. 414, http://bbc.mbp.org.pl/dlibra/docmetadata?id=10185\&from=pubindex \&dirids=1\&lp=702 (dostęp: 10.11.2019).

${ }^{54}$ Jedno z wydań, m.in.: Selecta latini sermonis exemplaria e scriptoribus probatissimis ad Christianae iuventutis usum, a p. Chompré... excerpta et ad editionem parisiensem recusa; prima excerptio poeticae orationis, Altenburgi, ex officina Richteria 1756, https://www.europeana.eu/portal/ pl/record/9200110/BibliographicResource_1000126608453.html (dostęp: 10.11.2019); albo: Pierre Chompré, Selecta Latini Sermonis Exemplaria, e scriptionibus probatissimis excerpta A.P. Chompré, typ. Joan Thom. de Trattner, Vindobonae 1778.

55 Jedno z wydań: [I tytuł:] L.A. Seneka, Ksiąg Pięcioro; [II tytuł:] Luciusz Anneusz Seneka, O krótkości życia, o życiu szczęśliwym, o opatrzności, o pokoiu duszy, o stałości mądrego Ksiag Pięcioro przekładania X. Dawida, druk. J.K. Mci i Rzeczy pltey Akademickiey Soc. Jesu, Wilno 1771; L. A. Seneka, Ksiąg Pięcioro; [III tytuł:] Luciusza Anneusza Seneki O krótkości życia, o życiu szczęśliwym, o opatrzności, o pokoiu duszy, o stałości mądrego Ksiag Pięcioro przekładania X. Dawida Pilchowskiego Societatis Jesu, ed. druga, druk. J.K. Mci Akademickiey, Wilno 1792; Estr., t. 27 , s. 376 .

${ }^{56}$ Jakub Klisiewicz [Ambroży X. od S. Laurentego Scholarum Piarum], Zebranie życia y historyi B. Józefa Kalasantego, fundatora szkół pobożnych. Przez niektóre przykłady o tym co B. Józef $z$ dziecinnych lat czynit y które dobrodzieystwa dziatkom nieustannie świadczyt wraz z nabożeństwem do tegoż blogosławionego patryarchy krótko napisane, druk. J.K. Mci y Rzplitey w Koll. XX. Sch. Piarum, 1753; Estr., t. 19, s. 300. 
[33] 1198 Epigrammatum problemata ${ }^{57} \mathrm{w}$ papier oprawne pół kopiejki

[34] 1199 Les odes de p. deronsard ${ }^{58}$ tom dwunasty w papier oprawne kopiejka jedna

[35] 1200 Edukacya katolicka iest Najwyższym dobrem kraiu ${ }^{59}$ bez oprawy pół kopiejki

[36] 1201 Novus candidatus Retoricae auctus ${ }^{60} \mathrm{~W}$ półskórek zużyty oprawne pół kopiejki

[37] 1202 Nouveaux essais d'Education ${ }^{61}$ tom trzeci, w papier oprawne kopiejka jedna

[k. 3] [38] 1203 Organizacya Szkoły Gorzkowskiey ${ }^{62}$ w papier oprawna pół kopiejki

[39] $1204 \mathrm{M}$. Tulli Ciceronis de officis xięgi $\operatorname{trzy}^{63} \mathrm{w}$ papier oprawne kopiejki trzy [40] 1205 Luci Annei Flori Rerum Romanorum cztery Xsięgi ${ }^{64}$ razem w papier oprawne kopiejek trzy

${ }^{57}$ Martinus Brzyski, Epigrammatum problemata ex variis poëtarum classicorum authoribus. Alphabeticè. Collecta concinnè polonico idiomate explicata. Cuivis statui hominū utilia. Authore Martino Brzyski, Typis S. R. M. Coll. Societ. Jesu, Lublinen 1765.

${ }^{58}$ Jedno z wydań, m.in.: Pierre de Ronsard, Odes, (1551-1552); Pierre Ronsard, Ode de la paix, G. Cavellat, Paris 1550; Les Odes de P. de Ronsard..., G. Buon, Paris 1573; Les Odes..., G. Buon, Paris $1586 \mathrm{i}$ inne edycje, https://catalogue.bnf.fr/changerPage.do?motRecherche=ronsard+pierre\&nbResultParPage $=10 \&$ afficheRegroup $=$ false \&affinageActif $=$ false \&pageEnCours $=10 \&$ nbPage $=184 \&$ trouveDansFiltre $=$ NoticePUB\&triResultParPage $=0 \&$ critereRecherche $=0$ (dostęp: 10.11.2019).

${ }^{59}$ Leopold od św. Avertana, Edukacya katolicka iest dobrem naywyższym kraju, jest szczęśliwościa w szczególności każdej osoby gdy ja posiada i wedlug niej żyje, druk. J.C.K.M. XX. Trynitarzów, Lublin 1807, http://bc.wbp.lublin.pl/dlibra/docmetadata?id=10854\&from=pubindex\&dirid$\mathrm{s}=22 \& \mathrm{lp}=505$ (dostęp: 10.11.2019).

${ }^{60}$ Jedno z wydań: Józef Juvencius (Jouvancy), Novus candidatus Rhetoricae, auctus, emendatus et perpolitus, Brunsberg 1735. Inne wydania: Lublini 1746, Calisii 1753, Posnaniae, 1753, Brunsbergae, 1755; Estr., t. 7, s. 695.

${ }^{61}$ Oliver Goldsmith, Nouveaux essais d'education, traduits de l'anglais et accompagnés et remarques par A. H. Dampmartin, Paris 1803, 1805, https://catalogue.bnf.fr/ark:/12148/cb30519700j (dostęp: 10.11.2019).

${ }^{62}$ Grzegorz Wężyk, Organizacya szkoty gorzkowskiey Towarzystwu Przyjaciół Nauk w Lublinie w celu rozszerzenia oświecenia publicznego (...) drukiem wyiaśniona, druk. Jana K. Pruskiego, Lublin 1820; Estr. XIX, t. 5, s. 47.

${ }^{63}$ Jedno z wydań: M.T. Cicero; De officiis libri tres, dein Laelius et Cato major et Somnium Scipionis, cum Paradoxis, castigate impressi, adiecto indice copiosissimo, doctoris Joannis Camertis, Viennae Pannouiae in aedib. Hieron. Vietoris et Joan. Singreuii socior. Expensis vero Leonhardi et Lucae Alantseae fratrum. Quarto nonas Januaarii 1512; Officia Ciceronis, mvlto qvam antea castigatiora, cvm scholiis Phil. Melan. quae possint esse uiae prolixi commentarij. Nam pleriq; loci, quos hactenus nemo attigit, hic enarrantur, apud Hiero. Vieto., Cracouiae 1528. Łącznie ukazało się 10 wyd. do 1680 r.; Estr., t. 14, s. 257-258.

${ }^{64}$ Jedno z wydań [Lucius Annaeus Florus], Epitome Rerum Romanorum: libri IV; polski przekład: L. Julivsza Flora o Początku y Dzieiách Narodu Rzymskiego Powieści Xiag IV. Abo historya Wielmożnego tego Narodu, od początku iego, aż do Augustá Cesarza, iako się począt, iako się wolności dostawszy rządzit, y iako wolność straciwszy, pod iednego Pana władza przyszedt. Z łaćińskiego na polski ięzyk przetlumaczona przez Krzysztofa Grotha Falissowskiego. Przydany iest traktacik 
[41] 1206 List prowincjonalnego do Warszawskiego filozofa ${ }^{65} \mathrm{w}$ papier oprawne pół kopiejki

[42] 1207 Rozmowa filozoficzna ${ }^{66}$ w półskórek oprawna kopiejki dwie

[43] 1208 Księga ustaw o ciężkich przestępstwach ${ }^{67} \mathrm{w}$ papier oprawna kopiejki trzy

[44] 1209 Dziennik Zdrowia ${ }^{68} \mathrm{Nr} 6$. bez początku oprawny kopiejka jedna

[45] 1210 Idzi Blas Niemiecki czyli przypadki Piotra Klauss część trzecia ${ }^{69}$ w półskórek oprawna kopiejki trzy

[46] 1211 Kmotr Maciej ${ }^{70}$ część pierwsza w półskórek oprawna kopiejek pięć

[47] 1212 Redukcya złotych na tynfy ${ }^{71}$ niekompletne w papier oprawne kopiejka jedna

[48] 1213 Compendium Instytutionum Gramaticarum Lingae Gallicae ${ }^{72} \mathrm{w}$ papier oprawne kopiejek dwie

[49] 1214 Zabawy przyjemne i pożyteczne ${ }^{73}$ Tomu 14. część pierwsza w połskórek oprawne kopiejek pięć

[50] 1215 Pamiętnik Naukowy ${ }^{74}$ i zarazem uwagi nad rapportem o więzieniach Królestwa Polskiego ${ }^{75}$ w półskórek oprawne kopiejek pięć

o przyczynach możności y potęi narodu tego, druk. Krzysztof Schedel J.K.M. Typograph, Kraków 1646; L. Julivsza Flora o Początku, u Bazylianów, Wilno 1790; Estr. t.16, s. 243.

${ }^{65}$ Augustin Barruel, Helwienki czyli Listy prowincyonalno-filozoficzne przez... dzieło (z francuskiego) z edycyi amsterd. r. 1785-88 thumaczone (przez ks. Kar. Surowieckiego), t. 1-5, Warszawa 1817-1819; Estr. XIX, t. 2, s. 97.

${ }^{66}$ Antoni Wiśniewski, Rozmowa Filozoficzna O Boskich procz Iestności Przymiotach Przeciw niegodziwie sobie przywłaszczaiacym nazwisko Deistow, Przez Filozofiy uczacych się Kawalerow In Varsaviensi Nobilium Collegio Scholarum Piarum Miana Roku MDCCLVIII, druk. XX. Schol. Piar., Warszawa (1758); Estr., t. 33, s. 72.

${ }^{67}$ Jedno z wydań: Księga ustaw na zbrodnie i ciężkie policyjne przestępstwa, cz. 1 O zbrodniach, Druk. Józefa Jerzego Trafslera, Kraków 1804; albo: Księga ustaw na zbrodnie i ciężkie policyjne przestępstwa, druk. J. Trasslera, Kraków 1804; lub: Księga ustaw na zbrodnie i ciężkie policyjne przestepstwa, druk. Pillera, cz. 1-2, [cz. 2, O ciężkich przestępstwach policyjnych i o sposobie $z$ temiż postępowania], Lwów 1804. Przypis 34.

68 „Dziennik Zdrowia, dla wszystkich stanów”, Warszawa 1801-1802, wyd. Leopold Lafontaine, miesięcznik; Estr. XIX, t. 3, s. 403.

${ }^{69}$ Adolf Franciszek Knigge, Idzi Blass, czyli przypadki Piotra Klaus, Kraków 1798; cz. 1-3, Kraków 1808; Estr. XIX, t. 17, s. 22.

${ }^{70}$ Józef Rychter, Kmotr Maciej, z niem. przez Augustyna Kadyi, t. 1-2, ed. nowa, druk. Groblowej, Kraków 1809; Estr. XIX, t. 4, s. 148.

${ }^{71}$ Taryffy rozmaite wzglendem monety tak tynfów na złote: y redukcya złotych na tynfy wedlug kurrencyi to iest rachuiac..., b.r.; Estr., t. 20, s. 55.

${ }^{72}$ Możliwe wydania: Georg Vignes, Compendium Instytutiorum gramaticarum Lingae Gallicae, Calisi 1747; Georg Vignes, Compendium, typis S.R.M. Colleg. Soc. Jesu, Lublini 1751; Estr., t. 32 , s. 500 .

73 „Zabawy Przyjemne i Pożyteczne”, Warszawa 1769-1777, tygodnik literacki; Estr., t. 3, s. 489.

74 „Pamiętnik Naukowy” (cd. „Ćwiczeń Naukowych”), Warszawa 1819; albo: „Pamiętnik Naukowy" (miesięcznik), Kraków 1837-1838; Estr. XIX, t. 3, s. 444.

${ }^{75}$ Jan Dekert, Uwagi nad częścia wyjątku z rapportu Fryderyka hrabi Skarbka. o więzieniach Królestwa Polskiego umieszczoną w N. 60 Gazety Warszawskiey 1832 roku, 1832; Estr. XIX, t. 4, s. 70. 
[51] 1216 Helikonki autora zebranych wierszów ${ }^{76}$ w półskórek oprawna kopiejek pięć

[52] 1217 Pisma Konstantyna Tymienieckiego ${ }^{77}$ oprawne kopiejek piętnaście

[k.4] [53] 1218 Historya Jakobinizmu ${ }^{78}$ tomów 4 w półskórek oprawne kopiejek sześćdziesiąt

[54] 1219 Budowanie wieyskie ${ }^{79}$ edycya druga kopiejek dziesięć

[55] 1220 Historya Męki zbawiciela ${ }^{80}$ W safian oprawna w futerale kopiejek trzydzieści

[56] 1221 Listy moralne z dzieł Eduarda Jounga ${ }^{81}$ w półskórek oprawne kopiejek trzy

[57] 1222 Kalendarzyk kieszonkowy Warszawski na rok 1833 i polityczny na rok 1843 w papier oprawny pół kopiejki

${ }^{76}$ Ksawery Zubowski, Helikonki Autora Zebranych Wierszow. X. Z. Spes nostra in calamo est, Heliconiadumque favore Cochanovius, druk. XX. Trynitarzów, Lublin 1789; Estr., t. 25, s. 150.

${ }^{77}$ Konstanty Tymieniecki, Pisma, cz. 1-2, Warszawa 1817; Estr. XIX, t. 4, s. 584.

${ }^{78}$ Augustyn Barruel, Historya jakobinizmu, wyięta z dziet (...) Mémoires pour servir à l'Histoire du Jacobinisme, thum. Karol Surowiecki, t. 1-4, Berdyczów 1812; Estr. XIX, t. 2, s. 97. W wersji oryginalnej: Augustin Barruel, Mémoires pour servir à l'histoire du jacobinisme, vol. 1-5, P. Fauche, Hambourg 1798-1799, 1803, 1818.

${ }^{79}$ Piotr Świtkowski, Budowanie Wieyskie Dziedzicom Dobr Y Possessorom toż wszystkim iakązkolwiek zwierzchność po wsiach i miasteczkach maiacym Do Uwagi y Praktyki Podane, nakł. i druk. Michała Grölla, Warszawa, Lwów 1782, wyd. 2, druk. Michała Grölla, Warszawa 1793; lub Piotr Świtkowski, Budownictwo Wieyskie wygodzie Dziedziców zwierzchników wsi naszych i miasteczek, cz. 1 z figurami, edycja nowa, nakł. autora, Warszawa 1794; Estr., t. 30, s. 110.

${ }^{80}$ Jedno z wydań, m.in.: [Passia], to iest Historya męki y śmierci Pana Jezusa Chrystusa ze czterech Ewangelistow krotko zebrana y na siedm części y z wyktady swymi rozdzielona, offic. Joannis Volrabi, Posnaniae 1582; [Passia], Historya o śmierci a męce Jezu Chrystusa Pana, z czterech ewangelistów zebrana, przez Jana Fabricjusza, Królewiec 1615; [Passia]. O męce śmierci i pogrzebie pana naszego Jezusa ze wszystkich czterech Ewangelii porzadnie zebrana, Gdańsk 1632, 1690; albo Postille catholiczney Część Trzecia. W którey się zamykaia kazania na święta Panny Mariey, Apostołow, Męczennikow y innych Swiętych, ktorych święta kościol zwykt obchodzić przez caly rok. Przydane sa y żywoty niektorych, z pewnych Historyi zebrane, Przydana iest, y Passia, to iest Historya męki Pana Zbawiciela naszego, Przez Doctora Jakuba Wuyka z Wagrowca Theologa Societatis Iezv; Estr., t. 24, s. 106; Estr., t. 33, s. 389-390. W XVIII-XIX w. wyd.: Królewiec 1720, 1754, Królewiec 1823, Kraków 1834; Katalog Biblioteki Narodowej, https://katalogi.bn.org.pl/discovery/se$\operatorname{arch}$ ?query=any,contains,passya $\&$ tab $=$ LibraryCatalog \&search_scope $=$ NLOP_IZ_ NZ\&vid=48OMNIS_NLOP:48OMNIS_NLOP\&lang=pl\&offset=0 (dostęp: 10.11.2019). Ponadto: Przemysław Domiechowski, Matka bolesna P. Marya. Historya męki Chrystusowey opisana i przez X. Przemystawa Prawdzica Domiechowskiego do druku podana, druk. Łuk. Kupisza, Kraków 1650; Estr., t. 15, s. 281.

${ }^{81}$ Listy moralne z dziel Edwarda Jounga, z francuskiego na polski przełożone, Lublin 1787; Estr., t. 33, s. 493. 
[58] 1223 Hrabia Waltron czyli subordynacya drama ${ }^{82}$ oraz Tryumf Łaskawości ${ }^{83}$ komedya w półskórek razem oprawne kopiejek siedm i pół

[59] 1224 Dzieła Saint Reala ${ }^{84}$ tom czwarty oraz pamiętnik Xnej Mazuryni ${ }^{85}$ razem w półskórek oprawne kopiejek pięć

[60] 1225 Sermons de M. Massillon careme ${ }^{86}$ Tom 1. 3 i 4. w papier kolorowy oprawne kopiejek czterdzieści pięć

[61] 1226 Sermons de M. Massillon a vent ${ }^{87}$ w papier kolorowy oprawny kopiejek piętnaście

[62] 1227 Sermons de M. Massillon petit caremae ${ }^{88}$ w papier kolorowy oprawny kopiejek piętnaście

[63] 1228 Sermons de M. Massillon panegiriques ${ }^{89}$ w papier kolorowy oprawny kopiejek piętnaście

${ }^{82}$ Henryk Ferdynand Moller, Hrabia Waltrori [Waltron] czyli subordynacya, dramma w piaciu aktach z francuzkiego P. Ebertsa przettomaczona, druk. Piotra Dufour, Warszawa 1784; Estr., t. 22, s. 522. W XVIII-XIX w. wyd. Królewiec 1720, 1754, Królewiec 1823, Kraków 1834.

${ }^{83}$ Antoni Michniewski, Tryumf łaskawości komedya w trzech aktach dla Teatru warszawskiego napisana przez X. A. T. Michniewskiego P.S., 1775; Estr., t. 22, s. 347.

${ }^{84}$ Saint-Real Cesar Vischard, Dzieła, tłum. Franciszek Zabłocki, t. 1-3, druk. Piotra Dufoura, Warszawa 1799; Estr., t. 27, s. 25; albo w wersji oryginalnej: Saint-Réal de César, Oeuvres, La Haye 1721; Saint-Réal de César, Oeuvres (...) Nouvelle édition augmentée, P. Mortier, Amsterdam 1730; Saint-Réal de César, Oeuvres [...] nouvelle édition revue, corrigée et augmentée, t. 1-6, F. L’Honoré et fils, Amsterdam 1740, https://catalogue.bnf.fr/ark:/12148/cb340028896 (dostęp: 10.11.2019); Saint-Réal de César, Les Oeuvres (...) Nouvelle édition, rangée dans un meilleur ordre et augmentée, t. 1-6, Paris, Ganeau 1745, https://catalogue.bnf.fr/ark:/12148/cb34002891r (dostęp: 10.11.2019).

${ }^{85}$ Jedno z wydań: Hortense Mancini, Mémoires de Madame la duchesse Mazarin, b.m., b.r., https://catalogue.bnf.fr/ark:/12148/cb39335173f (dostęp: 1.09.2019); Mémoires D. M. L. D. M., P. du Marteau, Cologne 1675; albo Marie Mancini, La Vérité dans son jour, ou le Véritables mémoires de M. Mancini connétable, Collone ok. 1678; albo Mémoires de Madame La Duchesse de Mazarin seraient d' Hortense Mancini elle-même et faussement attribués à Mme Du Rhut et l'abbé de SaintRéal; Lever donne comme auteur l'abbé de Saint-Réal avec l'argument que ce texte figure constamment dans les Oeuvres complètes de Saint-Réal à partir de l'édition de La Haye 1722, https://catalogue.bnf.fr/ark:/12148/cb30387585t (dostęp: 10.11.2019).

${ }^{86}$ Część jednego z licznych wydań dzieł francuskiego kaznodziei: Jean-Baptiste Massillon, Oeuvres, t.1-15, Lyon 1810; Jean-Baptiste Massillon, Oeuvres complètes, t. 1-14; t. 2-5. Sermons pour le carême, Gauthier frères, Besançon 1822; Jean-Baptiste Massillon, Oeuvres, Mequignon-Havard, Paris 1824; Jean-Baptiste Massillon, Oeuvres complètes. Nouvelle édition, augmentée d'un Discours sur sa vie et ses écrits, par M. le Cte O'Mahony, Méquignon-Havard, Paris 1826. Inne wydania: Paris 1828, Besançon 1822, Lille (b.r.), Paris 1830, Paris 1843, https://catalogue.bnf.fr/ rechercher.do; jessionid=40DAA08DFAFAAEA3AD797FA7644ADCB5? motRecherche $=$ Oeuvres + compl $\% \mathrm{C} 3 \%$ A 8 tes + de + Massillon \& critere Recherche $=0 \&$ depart $=0 \&$ facetteModifiee $=$ ok (dostęp: 10.11.2019).

${ }^{87}$ Część jednego z wydań Jean-Baptiste Massillon, Ouvres complètes, t. 1. Notice sur Massillon, par Gence. Sermons pour l'avent; przypis 73.

${ }^{88}$ Jedno z licznych wydań: Jean-Baptiste Massillon, Sermons de m. Massillon, Petit carême, Paris 1757; co najmniej 14 wydań do $1833 \mathrm{r}$.

${ }^{89}$ Jean-Baptiste Massillon, Oeuvres complètes, t. 9. Panégyriques, liczne wydania, m.in. Besançon, Gauthier frères, 1822, https://books.google.pl/books?id=gLLsSUsZrzIC\&pg=PA33\&lpg=PA33 
[64] 1229 Sermons de M. Massillon oraisons funebres et professions Religieuses ${ }^{90}$ w papier kolorowy oprawne kopiejek piętnaście

[65] 1230 Sermons de M. Massillon Mysteres ${ }^{91}$ W papier kolorowy oprawne kopiejek piętnaście

[k. 5] [66] 1231 Budownictwo wieyskie ${ }^{92} \mathrm{w}$ półskórek oprawne kopiejek siedm

[67] 1232 Miłostki i życie mężów greckich ${ }^{93}$ Tomów 2 w jednej książce w półskórek oprawne kopiejek siedm i pół

[68] 1233 Filozofka Europejska przeciw Chińskiemu Mandarynowi ${ }^{94}$ w półskórek oprawne kopiejek pięć

[69] 1234 Dlaczego komedya ${ }^{95}$ fedra i żona Tezeusza ${ }^{96}$ Tragedya razem w półskórek oprawne kopiejek siedm i pół

[70] 1235 Zwierciadło niezawodne o poznaniu siebie samego ${ }^{97}$ w półskórek oprawne kopiejek dwie

[71] 1236 Anegdoty Fryderyka II ${ }^{98}$ w półskórek oprawne kopiejek siedm i pół

$\& \mathrm{dq}=$ Sermons $+\mathrm{de}+$ Massilion $+\mathrm{a}+$ vent\&source $=\mathrm{bl} \&$ ots $=$ Pm2tj8dUf\&sig $=$ ACfU3U22ivX4lbK1xEUw7kQ2CFrm81Ft9Q\&hl=pl\&sa=X\&ved=2ahUKEwiJ26iuqe3hAhVok4sKHcsUAYkQ6AEwBnoECAcQAQ\#v=onepage $\& \mathrm{q}=$ Sermons $\% 20 \mathrm{de} \% 20$ Massilion $\% 20 \mathrm{a} \% 20 \mathrm{vent} \& \mathrm{f}=-$ false (dostęp: 10.11.2019).

${ }^{90}$ Jean-Baptiste Massillon, Oeuvres complètes, t. 8. Oraisons funèbres et professions religieuses.

${ }^{91}$ Jean-Baptiste Massillon, Sermons: Mystères, Paris 1745; Jean-Baptiste Massillon, Oeuvres complètes, t. 7. Mystères.

${ }^{92}$ Jedno z opracowań: Franciszek Rausch von Traubenberg, Budownictwo Wieyskie Do Gospodarskich Potrzeb Stosowne, A do Użycia Kraiowego Podane, druk. XX. Scholarum Piarum, Warszawa 1788; Estr., t. 26, s. 136; albo Piotr Aigner, Budownictwo wieyskie z cegty glino-suszoney, z plantami chatup wieyskich, stosownie do gospodarstwa narodowego przez (...), druk. Piotra Zawadzkiego, Warszawa 1791; lub Piotr Świtkowski X., Budownictwo Wieyskie Pożytkowi i wygodzie Dziedziców Zwierzchnikow Wsi naszych i Miasteczek. Poswięcone Przez (...), cz. I. z Figurami, edycya Nowa, koszt. Autora, Warszawa 1794; Estr., t. 12, s. 79.

${ }^{93}$ Miłostki dawnych filozofów y dawnych bohatyrów starożytnych, t. 1-2, Supraśl 1788; Estr., t. 22 , s. 392.

${ }^{94}$ Filozofka europejska przeciw chińskiemu mandarynowi, czyli Odpowiedź na rozprawe mandaryna ogłoszona w ruskim i francuskim języku o kobietach, thum. L[udwika] Dz[ieduszycka], Warszawa 1820; Estr. XIX, t. 5, s. 285.

${ }^{95}$ August Anicet Bourgeois, Dlaczego? Kom. w 1 a., tlum. Eugeniusz Scribe, Halpert B., druk. Zawadzki i Węcki, Warszawa, Merzbach 1834; Estr. XIX, t. 4, s. 270.

${ }^{96}$ Jan Racine (Rasyn), Fedra, tragedya, przetłómaczona, nakł. i druk. Grölla, Warszawa 1787; Estr., t. 26, s. 7.

${ }^{97}$ Zwierciadto niezawodne albo nauka y rozumowi do uznania prawd y woli do sprawowania cnot. O poznaniu siebie samego podana $w$ siedmiu uwagach na każdy w tygodniu dzień rozłożonych przełożona w ięzyku włoskim przez W. X. Pawła Segnerego S. J. po tym w Dilindze na łaciński a teraz z łacińskiego na polski wyttumaczona przez W. X. Piotra Radominskiego, druk. J. K. M., Kalisz 1778; Estr., t. 27, s. 347.

${ }^{98}$ Fryderyk II, Anekdoty czyli znamiona, charakter i przymioty Fryderyka II. króla pruskiego wystawujące. Przełożone z niemieckiego na polskie, druk. Akademicka, Wilno 1796; Estr., t. 16, s. 348 . 
[72] 1237 Cyrulik paryski Romans ${ }^{99}$ Tomów cztery w półskórek oprawne kopiejek trzydzieści

[73] 1238 Pan Podstoli100 dwie części w półskórek oprawne kopiejek dziesięć

[74] 1239 Kontynuacja Listów perskich część druga ${ }^{101}$ w półskórek oprawne kopiejek pięć

[75] 1240 Listy pewnego starca do młodego Xięcia pisane $\mathrm{z}$ roku 1751 rok $\mathrm{I}^{102}$ w półskórek oprawne kopiejek trzy

[76] 1241 Pisma pozgonne Szymona ${ }^{103} \mathrm{~W}$ półskórek oprawne kopiejek pięć

[77] 1242 Trzy córki wdowy. Romans ${ }^{104}$ tomów pięć w półskórek oprawne kopiejek trzydzieści

[78] 1243 Wszyscy błądzą czyli Sąd obojętny jednej filozofki ${ }^{105}$ w półskórek oprawne kopiejek dwie

[k. 6] [79] 1244 Klaudyusza Klaudyna o porwaniu Prozerpiny ${ }^{106}$ w półskórek oprawne kopiejek pięć

${ }^{99}$ Charles Paul de Cock, Cyrulik paryski, Przełożony z francuzkiego przez F.S. Dmochowskiego, t. 1-4, druk. przy ulicy Nowo-Senatorskiej Nro 476 Lit. D, Warszawa, (Merzbach) 1834; Estr. XIX, t. 17, s. 99.

${ }^{100}$ Ignacy Krasicki, Pan Podstoli, Na trzy księgi podzielony, nakł. i druk. Mich. Grölla, Warszawa 1778, 1784; Estr., t. 20, s. 224.

${ }^{101}$ Karol Montesquieu de, Kontynuacya Listów perskich P. de Montesquieu, przetłómaczona z francuskiego, cz. 2, Drezno 1778; Estr., t. 22, s. 542.

${ }^{102}$ Karol Tessin, Listy Pewnego Starca. [Drugi tytuł:] Listy Pewnego Starca Pisane Do Młodego Xiązęcia Po Niemiecku a Teraz Wyttumaczone Na Oyczysty Język przez P. A. G., u Jana Augusta Posera Bibliopoli, Warszawa 1780; Estr., t. 31, s. 114.

${ }^{103}$ Laurent Pierre Jussieu (de), Pisma pozgonne ś.p. Szymona. Dzieło przez Wawrzyńca de Jussieu napisane, (...), z francuzkiego na polski wolnie tłómaczone przez Edwarda R.(omera), nakł. i druk. J. Zawadzkiego, Wilno 1834; Estr. XIX, t. 12, s. 503.

${ }^{104}$ Wiktor Henryk Józef Brahain Ducange, Trzy córki wdowy, romans (...) przełożony z francuskiego przez F. S. Dmochowskiego, t. 1-5, druk. przy ulicy Nowosenatorskiej, Warszawa, Merzbach 1833; Estr. XIX, t. 5, s. 201.

${ }^{105}$ Klaudiusz Cyprian Ludwik Abrassevin, Wszyscy błądza czyli sprawa z obudwu stron niestuszna albo sąd jednéj damy filozofki w teraźniejszych okolicznościach jezuitów francuzkich, r. 1762 wydany, a z francuzkiego przetlumaczony w polskim języku do druku podany od N. N., Kraków 1803; Est. XIX, t. 1, s. 19.

${ }^{106}$ [Claudius Claudianus], Klaudysza Klaudyana, O Porwaniu Prozerpiny. Ksiag III. etc. przekładania Andrzeia Wincentego z Unichowa Ustrzyckiego. Edycya po pierwszey Warszawskiey 1689. po drugiey Krakowskiey 1700. Trzecia: przydatkiem nowym dziet rymotworskich tegoż autora, od innych przełożonych powiększona, nakł. Michała Gröla, Warszawa 1772; Estr., t. 14, s. 295. 
[80] 1245 Sonety i różne wiersze w upominku dla Polek na rok $1829^{107}$, Joanna Grei poema Jounga ${ }^{108} \mathrm{i}$ Homera Bitwa żab z myszami ${ }^{109}$ razem w półskórek oprawne kopiejek siedm i pół

[81] 1246 Wiersze polskie z fragmentow łacińskich złożone, dla zabawy umysłu i pożytecznej Nauki ${ }^{110}$ oraz przydatek do tychże wierszów razem w półskórek oprawne kopiejek trzy

[82] 1247 Porządek życia Tyssota ${ }^{111}$ w skórkę oprawne kopiejek siedm i pół

[83] 1248 Karolina Lichtfield Romans ${ }^{112}$ tomów trzy w półskórek oprawne kopiejek trzydzieści

[84] 1249 Powieść moralna o Lindodze ${ }^{113} \mathrm{~W}$ półskórek oprawne kopiejek pięć

[85] 1250 Niestałość $\mathrm{w}$ miłości ${ }^{114} \mathrm{w}$ półskórek oprawne kopiejek pięć

[86] 1251 Dobra Gospodyni ${ }^{115}$ w półskórek oprawne kopiejek pięć

[87] 1252 Estella Miłostki pasterskie ${ }^{116}$ w półskórek oprawne kopiejek pięć

${ }^{107}$ Stanisław Bratkowski, Sonety i różne wiersze w upominku dla Polek na rok 1829, przez S... B., Druk. Rządowa, Warszawa b.r. (1828); Estr., t. 2, s. 502.

${ }^{108}$ E. [dward] Young, Joanna Gray. Poema Edwarda Junga, autora Sąu Ostatecznego. Przektad z angielskiego przez St. Chr., Warszawa 1828; za Z. Sinko, Z zagadnień recepcji „, Sądu Ostatecznego” $i$ „,Myśli nocnych” Edwarda Younga, „Pamiętnik Literacki”, 65 (1974) z. 2, s. 97; Estr., t. 5, s. 213 nie notuje tego tytułu.

${ }^{109}$ Homer, Batrachomyomachia czyli Bitwa Żab z Myszami wierszem oyczystym wyłożona przez Jacka Przybylskiego Bibliotekarza i Starożytności Professora. Aut prodesse aut delectare, Druk. Szkoły Główney Koronney, Kraków 1789; Estr., t. 18, s. 255.

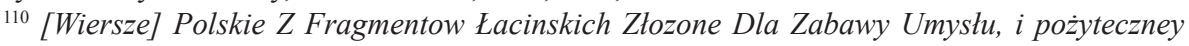
Nauki w rożnych Materyach, Przez pewnego Zakonnika Kapłana Wydane, druk. XX. Trynitarzów, Lublin 1785; Estr., t. 32, s. 474.

${ }^{111}$ Jedno z wydań: Szymon Andrzej Tissot (Tyssot), Porządek Życia w Czerstwości Zdrowia w Dlugie Prowadzacy Lata. Ze wszystkich dzieł P. Tyssota w iédno zebrany, druk. J.O.Xcia Mci Prymasa Arcybiskupa Gnieźnieńskiego, Kalisz 1789; Szymon Andrzej Tissot, Porzadek życia, $w$ czerstwości zdrowia $w$ dlugie prowadzacy lata, ze wszystkich dziet P. Tyssota $w$ iedno zebrany, druk. Bazylianów, Supraśl 1789, https://fbc.pionier.net.pl/details/nn7Rqwp (dostęp: 10.11.2019); Szymon Andrzej Tissot, Porządek życia, w czerstwości zdrowia w dlugie prowadzacy lata, ze wszystkich dziet P. Tyssota w jedno zebrany, a teraz przy trzeciem wydaniu przeyrzany, poprawiony y powiększony, druk. Prymas., Łowicz (1796), 1799; Estr., t. 31, s. 166.

${ }^{112}$ Izabela Montolieu (zm. 1833), Karolina Lichfield, Romans z dziet pani (...), t. 1-2, Henryk Emanuel Glücksberg, Wilno 1830; Estr., t. 3, s. 163.

113 Żądania (Troie). [Na drugiej k. tyt.:] Troie Żadania Czyli Powieść Moralna o Lindorze Umieiacym Pozwolonego Sobie Daru Rostropnie, i z Osobliwszym Użyć Pożytkiem. Z Przydanym Rozporzązeniem z Francuzkiego Na Polski Ięzyk Przełożona, druk. Michała Gröll, 1782; Estr., t. 34 , s. 71 .

${ }^{114}$ Argens J. B. de Boyer, Niestałość w miłości czyli awantury Markiza de Vandreville napisane po francuzku. przez Markiza d'Argens a teraz nowo przełożone na polski język przez Franc. Jaxyc Makulskiego, druk. Dufoura, Warszawa 1793; Estr., t. 12, s. 206.

${ }^{115}$ Gospodyni dobra, czyli fundamenta ekonomii gospodarskiey osobom młodym do tego stanu zabieraiacym się potrzebne, koszt. i druk. Ignacego Grebla, Kraków 1784.

${ }^{116}$ Claris Florian de, Estella, milostki pasterskie. Z dziel francuzkich pana Floryan. Tłomaczenia Jana Nowickiego, druk, Antoniego Ignacego Gröbla, Kraków 1796; Estr., t. 16, s. 241; Claris Florian de, Estella, miłostki pasterskie (...), druk. Tekli Gröblowej, 1806; Estr. XIX, t. 7, s. 155. 
[88] 1253 Dziennik Gospodarczo-Rolniczy ${ }^{117}$ Numerów dwa razem w półskórek oprawne kopiejek siedm i pół

[89] 1254 Polak w Paryżu ${ }^{118}$ część pierwsza w pólskórek oprawne pięć

[90] 1255 Pierwiastki Religii Katolickiej przez X. Wężyka ${ }^{119}$ w papier oprawne kopiejek trzy

[91] 1256 Historya kawalera polskiego ${ }^{120}$ niekompletna w półskórek oprawna kopiejek trzy

[92] 1257 Król pasterz opera ${ }^{121}$, Dziki amerykanin komedya ${ }^{122}$, Lunatyk komedya $^{123}$ pan poznany komedya ${ }^{124}$, na postrachu wszystko się zakończy Dramat ${ }^{125}$, razem w pólskórek oprawne kopiejek dziesięć

[93] 1258 Nieszczęśliwa Kastelli ${ }^{126}$ części dwie razem w półskórek [k. 7] oprawne kopiejek siedm i pół

[94] 1259 Linska Hrabina ${ }^{127}$ Tomów dwa niekompletne razem oprawne w półskórek kopiejek siedm i pół

117 „Dziennik Gospodarczo-rolniczy”, Warszawa 1812, kwartalnik; Estr., t. 3, s. 385.

${ }^{118}$ Polak w Paryżu albo dwutygodniowa w tymże mieście bytność hrabiego***, cz. 1-2, druk. P. Dufour, Warszawa 1787; Estr., t. 24, s. 435.

${ }^{119}$ Grzegorz Wężyk, Pierwiastki religii katolickiej, połaczone z dziełami pierwszych jej założycielów, cz. 1-2, druk. K. Szczepański, Lublin 1824; Estr. nie notuje tego tytułu, ale jest egz. w Bibliotece Wojewódzkiej im. H. Łopacińskiego w Lublinie, http://bc.wbp.lublin.pl/dlibra/docmetadata? $\mathrm{id}=2893 \&$ from $=\&$ dirids $=1 \&$ ver_id $=\& 1 \mathrm{p}=2 \& \mathrm{QI}=($ dostęp: 10.11.2019).

${ }^{120}$ Prechac, Historya Polska Polityczno-Moralna Walewskiego Kawalera Polskiego z Beralda Corka Graffa Romerszteyna. Feld-Marszałka Woysk Cesarza Chrześciánskiego. Awantury Przyiaźni. Opisuiąca z Francuskiego Języka ná Polski przettumaczona Jáśnie Oświeconemu Xiązęciu Jmći Stefanowi Altamorowi, Nayiaśnieyszego Augusta III Krola Polskiego, Elektora Saskiego, Woysk Saskich Porucznikowi, druk. XX. Scholarum Piarum, Warszawa 1754; Estr., t. 25, s. 230.

${ }^{121}$ Józef Kurtz, Król pasterzem. Balet heroiczno-pantomiczny wzięty z autora włoskiego (tak) Metastasio a ułożony przez P. Kurtza Balet Maystra w stużbie J. K. Mci i dany w dzień imienin J. K. M. dnia 8 maja na teatrze publicznym, druk. P. Dufour, Warszawa 1790; Estr., t. 20, s. 399.

122 [Louis François Delisle de La Drevetière] Arlekin Dziki Amerykanin Komedya Wyprawiona,Wilno, Coll. Nobilium Soc. Jesu,1765; albo: Louis François Delisle de La Drevetière, Dziki Amerykanin do Europy z Leliuszem przybyty. Komedya we trzech aktach, Warszawa 1778; Estr. t. 36 , s. 51.

${ }^{123}$ Lunatyk. Komedya, we dwóch aktach dla teatru warszawskiego z francuskiego przetlumaczona, druk. P. Dufour, Warszawa (1779); Estr., t. 21, s. 526.

${ }^{124}$ [Pan] poznany, komedya we trzech aktach, b. m. b. r. (17...); Estr., t. 24, s. 43.

${ }^{125}$ Stanisław Kublicki, Na postrachu wszystko się zakończy; dramma oryginalna we trzech aktach. Servibo Matris commodis. Plautus Hecyra Act. 3. Scen. 5, druk. i nakł. Michała Grölla, Warszawa (1780); Estr., t. 20, s. 351.

${ }^{126}$ Contant d'Orville, André-Guillaume, Nieszczęśliwa Kastelli Albo Listy Pani Hrabiny Kastelli Do Panny Baronowny D'Freville, cz.1-2, Kalisz 1778; Estr., t. 14, s. 388.

${ }^{127}$ Millon de Lavalle (La Valle), Lińska Hrabina, powieść Polska, Supraśl 1789; Estr., t. 22, s. 391. 
[95] 1260 Historya Pani Ernevil ${ }^{128}$ części dwie w półskórek oprawne kopiejek siedm i pól

[96] 1261 Antykwaryusz Romans ${ }^{129}$ w półskórek oprawny kopiejek trzydzieści

[97] 1262 Ewelina Romans ${ }^{130}$ Tomów cztery w półskórek oprawny kopiejek trzydzieści

[98] 1263 Wieniec $^{131}$ rok 1 i 2 . Tomów dwadzieścia cztery w trzynastu książkach w półskórek oprawne rubel srebrny jeden

[99] 1264 Kreol Romans ${ }^{132}$ Tomów trzy w pólskórek oprawne kopiejek dwadzieścia

[100] 1265 Hiszpanie w Peru Traiedya ${ }^{133}$, Małżeństwo przymuszone komedya ${ }^{134}$ razem w półskórek oprawne kopiejek kopiejek dziesięć

[101] 1266 Zbiór nazwy szlachty przez Małachowskiego ${ }^{135} \mathrm{w}$ półskórek oprawne kopiejek trzydzieści

[102] 1267 Sabaudczyk. Romans ${ }^{136}$. Tomów 4 w półskórek oprawny kopiejek trzydzieści

[103] 1268 Siostra Anna. Romans ${ }^{137}$ tomów cztery w półskórek oprawne kopiejek czterdzieści

[104] 1269 Opisanie różnych kraiów świata przez Contant de Will ${ }^{138}$ w półskórek oprawne kopiejek pięć

${ }^{128}$ Erneville, Historia Pani Ernewil od niey samey pisana z francuskiego na polski ięzyk przetozona roku 1783 dla zabawy ciekawego czytelnika do druku podana, cz. 1-2, druk. Pillerowskim, Lwów 1783; Estr., t. 16, s. 98.

${ }^{129}$ Walter Scott, Antykwariusz. Romans, przet. E. G., t. 1-4, wyd. F. S. Dmochowski, Warszawa 1828. Jest to cz. 4 edycji: W. Scott, Wybrane romanse, Warszawa 1828; Estr. XIX, t. 4, s. 269.

${ }^{130}$ Franciszka d'Arblay Burney, Ewelina czyli wyjście młodéj panny na scenę świata, romans, ttumaczony przez T. Hołonkiewicza, t. 1-4, nakł. i druk. Glücksberga księgarza i typografa Cesarskiego Uniwersytetu, Wilno 1830; Estr. XIX, t. 2, s. 626.

131 „Wieniec. Pismo dodatkowe miesięczne do Gazety Warszawskiej poświęcone literaturze”, Warszawa 1839-1841. (Wcześniej Tęcza, potem Echo); Estr., t. 3, s. 385.

${ }^{132}$ Heinrich Zschokke, Kreol, czyli rozbicie okrętu Austrya, t. 1-3, druk. Węcki, Warszawa, Orgelbrand 1833; Estr. XIX, t. 5, s. 310.

${ }^{133}$ Fryderyk August Kotzebue (Kocebue), Hiszpanie w Peru albo śmierć Rolli. Tragedya przez (...) napisana, a przez Alexan[dra] Chodkiewicza przettómaczona w 5 aktach, roku 1797. (b.m. b.dr.); Estr., t. 20, s. 169.

${ }^{134}$ Molière (Jan Chrz. Poquelin), Matżeństwo przymuszone. (Matżeństwo z musu). Kom. $w$ dwóch aktach z francuzkiego Pana Molière przetłomaczona y przez Aktorów J. K. Mci narodowych na teatrze publicznym reprezentowana, druk. P. Dufour, Warszawa 1782; Estr., t. 11, s. 516.

${ }^{135}$ Piotr N. Małachowski, Zbiór nazwisk szlachty z opisem herbów [własnych zostających w Królestwie Polskim i Wielkim księstwie Litewskim], Lublin 1805; Estr., t. 3, s. 56.

${ }^{136}$ Charles Paul Kock, Sabaudczyk czyli miłość $i$ wdzięczność. Romans obyczajowy (...) przetożony z francuzkiego przez F. S. Dmochowskiego, t. 1-4, druk. przy ulicy Nowo-Senatorskiej Nro 476 Lit. D, Warszawa 1835; Estr. XIX, t. 17, s. 99.

${ }^{137}$ Charles Paul Kock, Siostra Anna, romans obyczajowy (...) przełożony w języku oyczystym przez W. O.(lechowskiego), t. 1-4, nakł. Huguesa księgarza, druk. J. Węckiego, Warszawa 1835; Estr. XIX, t. 17, s. 99.

${ }^{138}$ Contant Dorville, Opisanie naturalne, historyczne y polityczne roznych kraiow świata to jest ich położenie, Klima, Historya, Rewolucye, rzą, potęa, prawa, zwyczaie, sądy, rękodzieła, han- 
[105] 1270 Prezent dla żon ${ }^{139}$, Józef poznany ${ }^{140}$, prezent dla gospodyni ${ }^{141}$ i Biały i Czarny ${ }^{142} \mathrm{~W}$ półskórek oprawne kopiejek siedm i pół

[106] 1271 Rynaldo Rynaldyni ${ }^{143}$ tomów 2 w półskórek oprawne [k. 8] kopiejek piętnaście

[107] 1272 Czytania zabawne czyli wybor anegdotów ${ }^{144}$ w półskórek oprawne kopiejek pięć

[108] 1273 Xiądz Pleban ${ }^{145}$ część pierwsza w półskórek oprawne kopiejek pięć

[109] 1274 Zabawy przyjemne i pożyteczne ${ }^{146}$ i dociekania o człowieku ${ }^{147}$ razem w półskórek oprawne kopiejek siedm o pół

[110] 1275 Cztery wesela ${ }^{148}$ tomów dwa w półskórek oprawne kopiejek pięć

[111] 1276 Rękopism nadesłany z wyspy Św. Heleny ${ }^{149}$ w półskórek oprawny kopiejek pięć

[112] 1277 Bajki Krasickiego ${ }^{150}$ w półskórek oprawne kopiejek trzy

del, bogactwa, miny, urodzaie, Religia, zabobony, Kościoły, Kapłani, nauka, wesela, pogrzeby, stroy, rzadkie ptastwa, zwierzęta, ryby, tlum. z franc. Joachim Karwowski, druk. XX. Scholarum Piarum, Warszawa 1774; Estr., t. 14, s. 388.

${ }^{139}$ Prezent dla żon z francuskiego przettumaczony, Warszawa, w Gröllowskiej Księgarni Nadworney Królewskiey, 1777; Estr., t. 25, s. 240.

${ }^{140}$ Jedno z wydań: Piotr Metastasio (Metastazy), Józef poznany, z włoskiego języka na polski przetlumaczone X.B. P.[opiela], Supraśl 1781, 1782; Estr., t. 22, s. 307.

${ }^{141}$ Prezent dla gospodyń z francuskiego przetlumaczony, Warszawa 1777; Estr., t. 25, s. 240.

${ }^{142}$ Franciszek Jaxyc Makulski, Biały i Czarny z francuskiego, b.m.w., 1790; Estr., t. 22, s. 63.

${ }^{143}$ Christian A. Vulpius, Rinaldo Rinaldini, herszt zbójców. Romans historyczny wieku osiemnastego, tlum. B. Kiciński, Warszawa 1814 i inne wydania; Estr. XIX, t. 6, s. 37 (ukazało się co najmniej 9 wyd. do 1884 r.).

${ }^{144}$ Czytania zabawne czyli wybor przygód, powieści moralnych i anekdotow, z rożnych autorow wybrane, a z francuzkiego na ięzyk polski wyłożone, , druk. Piotra Dufour, Warszawa 1786. Czytania zabawne, Kraków 1794; Estr., t. 14, s. 588.

${ }^{145}$ Józef Kazimierz Korwin Kossakowski, Xiądz Pleban. In aedificationem et non in destructionem, cz. 1, b.m., b.r., wyd. 2, t. 1, druk. M. Grölla, Warszawa 1788; Estr., t. 20, s. 138.

${ }^{146}$ Zabawy przyjemne i pożyteczne z sławnych wieku tego autorów zebrane, wyd. Jan Albertrandy, Gröll, Warszawa 1769 (1770)-1777; Estr., t. 3, s. 389; albo: „Zabawy Przyjemne i Pożyteczne”, Warszawa 1803-1807.

${ }^{147}$ Aleksander Pope, Dociekania o Człowieku czyli Początki Obyczayności. Dzieło Jmć Pana Pope. Przetlumaczone od Jmć P. Targońskiego, druk. XX. Trynitarzów, Lublin (1789); Estr., t. 25, s. 64.

148 J.I. Kraszewski, Cztery wesela, szkic fantastyczny z dodatkiem improwizacyi fantastycznej Byto nas dwoje, t. 1-2, Wilno 1834; Estr., t. 2, s. 475.

${ }^{149}$ Napoleon I, Rękopism nadesłany z wyspy św. Heleny niewiadomym sposobem, przełożony na polskie z francuskiego egzemplarza wydanego w Londynie u p. Murray, thum. F. Bentkowski, druk Zawadzkiego i Węckiego, Warszawa 1817; Estr., t. 3, s. 204.

150 Jedno z wydań: Ignacy Krasicki, Bajki i przypowieści na cztery części podzielone, nakł. i druk. Michała Grölla, Warszawa 1779, 1800; Estr., t. 20, s. 220; Ignacy Krasicki, Bajki i przypowieści tudzież Bajki nowe, druk. XX. Pijarów, Warszawa 1805, 1806; Ignacy Krasicki, Bajki i przypowieści dla użytku młodzieży szkolnej, Wilno 1815; Ignacy Krasicki, Bajki i przypowieści..., wyd. nowe, Wrocław 1817; Ignacy Krasicki, Bajki i przypowieści dla użytku dzieci przedrukowane, Kraków 1818. Ponadto ukazało się 14 innych wydań do 1845 r.; Estr. XIX, t. 2, s. 266-267. 
[113] 1278 Żywot Pana Jezusa ${ }^{151}$ w półskórek oprawne kopiejek dziesięć

[114] 1279 Pochwała Woronicza ${ }^{152}$ i gabinet czytania ${ }^{153}$ niekompletny razem w półskórek oprawne kopiejek pięć

[115] 1280 Godne pamięci zarysy życia Jenerała feldmarszałka ${ }^{154}$ Tomów sześć, nieoprawne kopiejek trzydzieści

[116] 1281 Historyczno-biograficzny rys życia feldmarszałka Warszawskiego ${ }^{155}$ kopiejek siedm i pół

[117] 1282 Ludwika Helnilg powieść ${ }^{156}$, psota małpy powieśćc ${ }^{157}$, Kasperek w szczęściu komedyo-opera ${ }^{158}$, Wolny malarz komedya ${ }^{159}$, Literat z biedy komedya ${ }^{160}$, razem w półskórek oprawne kopiejek dziesięć

[118] 1283 Zegar monarchów przez Guevarza ${ }^{161}$ Części trzy w skórę oprawny kopiejek pięć

[119] 1284 Doświadczyński dramat ${ }^{162}$ w półskórek oprawne kopiejek trzy

${ }^{151}$ Wydanie trudne do jednoznacznego ustalenia.

${ }^{152}$ Adam Jerzy Czartoryski, Pochwała Jana Pawła Woronicza, czytana na posiedzeniu Towarzystwa Przyjaciół Nauk dnia 30 Kwietnia 1830 r. przez (...) członka tegoż Towarzystwa, Puławy, b.r. (1830), wyd. 2, Warszawa 1830; Estr. XIX, t. 3, s. 357.

${ }^{153}$ Gabinet Czytania, tj. zbiór powieści, romansów tudzież artykułów nauce i zabawie poświęconych, w Księgarni F.S. Dmochowskiego, t. 1-3, Warszawa 1834-1835; Estr., t. 8, s. 13.

${ }^{154} \mathrm{G}$. Iwan, Godne pamięci zarysy z życia jenerat-feldmarszałka Księcia Warszawskiego hrabi Jana Teodorowicza Paskiewicza Erywańskiego i walecznych jego towarzyszów obejmujące w sobie Wszystkie wojenne zdarzenia trzech pamiętnych kampanjji: Perskiéj, Tureckiéj, i Polskiéj, które oręż Rossyjski wstawity, t. 1-6, druk. M. Chmielewskiego, Warszawa (t. 1-5), 1843, (t. 6), 1844; Estr., t. 8, s. 9.

155 J. Tołstoj, Historyczno-biograficzny rys życia feldmarszałka księcia feldmarszałka księcia warszawskiego hrabi Paskiewicza Erewańskiego namiestnika Królestwa Polskiego z fr. przeł. W. Zajączkowski, Warszawa 1840, wyd. 2, Warszawa 1840, wyd. 3, Warszawa 1841; Estr. XIX, t. 4, s. 510.

${ }^{156}$ Prawdopodobnie: Elizabeth Helme, Ludwika czyli odludne mieszkanie z angielskiego, przez JMci Panne, z angielskiego, P. Dufour, Warszawa 1789; Elizabeth Helme, Ludwika, edycja nowa, Le Brun, Warszawa 1802; Estr., t. 18, s. 89, http://dlibra.umcs.lublin.pl/dlibra/docmetadata?id=25 048\& from=pubindex \&dirids $=10 \& 1 p=905$ (dostęp: 10.11 .2019$)$.

${ }^{157}$ Niezidentyfikowane.

${ }^{158}$ Alojzy G. Żółkowski, Kasperek w szczęściu komedyja opera w 1 akcie przez... aktora teatru warszawskiego z francuzkiego przerobiona, druk. Gazety warszawskiej, Warszawa 1814; Estr. XIX, t. 5 , s. 325 .

${ }^{159}$ August Kotzebue, Wolny mularz. Kom. w 1 a., tlum.? K. Brodziński, Warszawa 1819; Estr. XIX., t. 19, s. 155.

${ }^{160}$ Jan Drozdowski, Literat z biedy. Kom. oryg. w 4 a., Warszawa 1784; Estr. 15, s. 4.

161 Jedno z wydań: Antoni Guevara, Zegar monarchów Cesarza Chrześciańskiego penitencyarza, kaznodzieię y dzieiopisa roku 1524, złożony w roku 1611 z Castelskiego włoskiego Języka na taciński przetożony, teraz dla zabawy domowey po szkolnych pracach przez urodzonego Antoniego Felixa Roszkowskiego polskim tłomaczony językiem, druk. Michała Wawrzyńca Pressera, Leszno 1751. Inne wydania: Poznań 1759, 1762, Wilno 1765, Lwów 1776, Wilno [b.r.]; Estr., t. 17, s. 461.

${ }^{162}$ Doświadczyński, czyli cnota uciemiężona do czasu. Drama w piąciu aktach. Wszak przyiaciel w potrzebie, w ogniu czystość złota; W przeciwnym losie szczęścia doświadcza się Cnota, nakł. i druk. Michała Grölla, Warszawa 1779; Estr., t. 15, s. 295. 
[120] 1285 O początku i postępie Instytutu Głuchoniemych w Warszawie ${ }^{163}$ w papier oprawne [k. 9] kopiejka jedna 1

[121] 1286 Opis Egiptu ${ }^{164}$ w półskórek oprawny kopiejki dwie

[122] 1287 Bajki i powieści przez Kurzewskiego ${ }^{165} \mathrm{w}$ papier oprawne z kopersztychami kopiejek pięć

[123] 1288 Obraz świata ${ }^{166}$ tomów dwa w półskórek oprawne kopiejek czterdzieści pięć

[124] 1289 Poezja Kniaźnina ${ }^{167}$ tom trzeci w półskórek oprawne kopiejek dziesięć

[125] 1290 Listy Napoleona ${ }^{168}$ tomów dwa w półskórek oprawne kopiejek piętnaście

[126] 1291 Skąpiec komedya ${ }^{169}$. Dwa dni w Szwajcarii saskiej ${ }^{170}$ i Historya obyczajów i Instynktu zwierząt ${ }^{171}$ tom pierwszy, część druga razem w półskórek oprawne kopiejek dziesięć

[127] 1292 Edmund przez Witwickiego ${ }^{172}$ w półskórek oprawne kopiejek siedm i pół

[128] 1293 Alzyra Tragedya ${ }^{173}$, Diabeł kulawy oraz rozmowy poważne i zabawne kominów Madryckich ${ }^{174}$ razem w półskórek oprawne kopiejek siedm i pół

${ }^{163}$ Jakub Falkowski, O początku i postępie Instytutu Warszawskiego Gtuchoniemych oraz niektóre iego urządzenia, dla wiadomości osób iakikolwiek związek z tymże Instytutem mieć mogących, Warszawa 1823; Estr., t. 7, s. 31.

${ }^{164}$ Fr. Celestyn Chasseboeuf Volney, Opis Egiptu podtug najnowszej podróży pana (...) z francuzkiego, krótko zebrany przez Jana Nowickiego, druk. Gröbla, Kraków 1800; Estr., t. 5, s. 148.

${ }^{165}$ Kurzewski, Bajki i powieści, Warszawa 1838; Estr. XIX, t. 2, s. 534.

${ }^{166}$ Tomasz Dziekoński, Obraz świata pod względem geografii, statystyki i historyi wszystkich krajów, skreślony podtug najlepszych źródet. Z mappami, herbami wszystkich państw i rycinami, t. 1-2, Warszawa, Merzbach 1843; Estr. XIX, t. 5, s. 301.

${ }^{167}$ Możliwe wydania: Franciszek Kniaźnin, Poezye, t. I, edycya zupetna, druk. Michała Grölla, Warszawa 1787; Franciszek Kniaźnin, Poezye, edycya zupetna podtug wydania roku 1787 i 1788 , druk. Michał Gröll; Estr. t. 19, s. 341; Franciszek Kniaźnin, Poezye, t. 1-3, nakł. Towarzystwa Typograficznego, druk. A. Marcinowskiego, Wilno 1820; Estr. XIX., t. 17, s. 16-17.

168 [Bonaparte Napoleon I], Listy Napoleona do Józefiny, podczas pierwszej wyprawy włoskiej Konsulatu i Cesarstwa pisane tudzież listy Józefiny do Napoleona i jej córki. Przekład z francuskiego przez Adama Rogulskiego, t. 1-2, J. Glücksberg, Warszawa 1835; Estr., t. 3, s. 203.

${ }^{169}$ Jan Chrzciciel Molier (Poquelin), Skapiec. Komedya w piaciu aktach z francuskiego na polski język przetłomaczona, P. Dufour drukarza, Warszawa 1778; Estr., t. 22, s. 515; Jan Chrzciciel Molier (Poquelin), Skapiec. Komedya, druk. Glücksberga, Warszawa 1822; Estr. XIX., t. 3, s. 155

${ }^{170}$ [Andrzej Edward Koźmian], Dwa dni w Szwaycaryi Saskiey w Roku 1825, przez A. E. K., druk. przy ulicy Mazowieckiej Nr 1349, Warszawa 1828; Estr. XIX., t. 2, s. 457.

${ }^{171}$ Juliusz Józef Virey, Historja obyczajów i instynktu zwierząt, t. 1-2, druk. Zawadzki i Węcki, Warszawa 1828, wyd. 2, Warszawa 1844; Estr., t. 5, s. 100.

${ }^{172}$ Stefan Witwicki, Edmund. Poem. dram., 1829; Estr. XIX, t. 5, s. 113.

${ }^{173}$ Franciszek Maria Arouet Voltaire, Alzyra tragedya w pięciu aktach z francuskiego na polski język przetlumaczona, druk. Dufour, Warszawa 1779; Estr., t. 33, s. 307.

${ }^{174}$ Prawdopodobnie: Alain Rene Lesage, Diabet kulawy, 1777; albo: [Jacques Cazzote], Diabet rozkochany. Nowina hiszpańska, przet. na polski język, 1783; Estr., t. 15, s. 167. 
[129] 1294 Listy i pisma różne ${ }^{175}$ tomów dwa razem w półskórek oprawne kopiejek pięć

[130] 1295 Dziwak komedya ${ }^{176}$ i dwaj zięciowie ${ }^{177}$ komedya razem w półskórek oprawne kopiejek dziesięć

[131] 1296 Juliana Niemcewicza pism różnych wierszem i prozą ${ }^{178}$ tom drugi w półskórek oprawne kopiejek siedm i pół

[132] 1297 Dziennik seymowy z r. $1820^{179}$ i krótki rzut oka na teraźniejszy stan kraiu ${ }^{180}$ razem w półskórek oprawne kopiejek pięć

[133] 1298 List pana Lawal ${ }^{181}$ w półskórek oprawne kopiejek pięć

[k.10] ]134] 1299 Komedya o dewodce ${ }^{182}$ w półskórek oprawne kopiejek trzy

[135] 1300 Przypadki Doświadczyńskiego Historya ksiąg dwie i Listy o ogrodach ${ }^{183}$ razem w półskórek oprawne kopiejek siedm i pół

[136] 1301 Python Lipsko-warszawski Diabeł kontrtragedya ${ }^{184}$ w półskórek oprawne kopiejek pięć

${ }^{175}$ Ignacy Krasicki, Listy i pisma różne X. B. W., t. 1, Warszawa 1786, nakł. i druk. Michała Grölla, t. 2, Warszawa 1788; Estr., t. 20, s. 222.

${ }^{176}$ Józef Bielawski, Dziwak, komedya we trzech aktach na dzień trzeci Augusta przez (...) Fligel-Adjutanta Buławy Wielkiey W. Xięstwa Littewskiego. Napisana y na Theatrum J. K. Mći grana. R. P. 1766, druk. Mitzlerowskiey, Warszawa [1766]; Estr., t. 13, s. 63; albo Nikodem Muśnicki, Dziwak, komedya etc., Połock 1800; Estr., t. 3, s. 183; albo Wacław Rzewuski, Dziwak komedya przez J. R. S. D. G. L. W. K., Lwów, druk. Akademickiey J. K. M. Coll. Soc. Jesu, b.m., b.r. (1760); Estr., t. 26, s. 553-554.

${ }^{177}$ Karol Wilhelm Étienne, Dwaj zięciowie. Kom. w 5 a., thumaczenia Pustelnika z Krakowskiego Przedmieścia (Gerarda Maurycego Witowskiego), druk. Zawadzkiego i Węckiego, Warszawa 1818; Estr., t. 6, s. 161.

178 Julian Ursyn Niemcewcz, Pisma różne wierszem i proza, t. 1-2, Warszawa 1803-1805.

${ }^{179}$ Dziennik posiedzeń Izby Poselskiey w czasie Seymu Królestwa Polskiego w roku 1820 odbytego, [Warszawa 1820].

${ }^{180}$ Krótki rzut oka na teraźniejszy stan kraiu i niektóre myśli, do ulepszenia dążace, przez iednego z Deputowanych ułożony, Warszawa 1820.

${ }^{181}$ Lawal, List byłego pastora $w$ Condé do swoich dawnych wspótwyznawców, wydany w Pary$\dot{z} u \mathrm{w}$ 1825, przetożony z francuskiego $w$ tymże roku przez pewnego Polaka ex-protestanta, u XX. Misjonarzy, Warszawa b.r. (po 1825); Estr., t. 2, s. 554.

${ }^{182}$ Christian Fürchtegott Gellert, Komedia o dewotce, Wrocław 1771; Estr., t. 17, s. 81.

${ }^{183}$ Ignacy Krasicki, Dzieła, edycja nowa, t. 1-10, u Fr. Dmochowskiego, Warszawa 1802-1804, t. 5: Listy o ogrodach; Ignacy Krasicki, Dzieła, edycja nowa i zupelna podtug wydania Fr. Dmochowskiego, t. 1-10, nakład i druk. Glücksberga, Warszawa 1829, t. 5: Doświadczyńskiego przypadki, Historia, Listy o ogrodach; Estr., t. 2, s. 466.

${ }^{184}$ Karol Surowiecki, Python, lipsko-warszawski diabet, kontr-tragedya na tragedyę Saul wyjęta z Pisma Świętego grana przez aktorów Tamtego Świata w roku 1792 Światu ziemskiemu objawiona, Warszawa (1792); Estr., t 30, s. 64. 
[137] 1302 Pierwsza miłość komedya ${ }^{185}$ i wszystko się skończyło na proiekcie tragedya ${ }^{186} \mathrm{~W}$ półskórek oprawne kopiejek pięć

[138] 1303 Oblężenie Płocka drama ${ }^{187}$, Belizar tragedia ${ }^{188}$, Córka znaleziona drama $^{189}$ i Łaska imperatora ${ }^{190}$ komedya razem w półskórek oprawne kopiejek siedm i pół

[139] 1304 Omyłka komedya ${ }^{191}$ w półskórek oprawna kopiejek trzy

[140] 1305 Izys Polska ${ }^{192}$ tom pierwszy w półskórek oprawna kopiejek dziesięć

[141] 1306 Samolub komedya ${ }^{193}$, wolny mularz komedya ${ }^{194}$, Germkowie króla Jana ${ }^{195}$ i Gaweł na księżycu ${ }^{196}$ razem w półskórek oprawne kopiejek siedm i pół [142] 1307 Sybilla poema historyczne ${ }^{197}$ razem w półskórek oprawne kopiejek trzy

${ }^{185}$ Franciszek Ksawery Błotnicki, Pierwsza miłość. Kom. w 1 a., b.m., b.r.; albo Scribe Eugeniusz, Pierwsza miłość, czyli Pamiątka dziecinności. Kom. w 1 a., tlum.? Jan Chodźko,Wilno 1837; albo Dyzma Bończa Tomaszewski, Pierwsza miłość, komedia w 3 aktach, druk. Gröbla, Lipsk (Kraków) 1805; Estr., t. 4, s. 514.

${ }^{186}$ Wincenty Ignacy Kościesza Marewicz, Wszystko się skończyło na projekcie. Komedya oryginalna we dwóch Aktach napisana przez Wincentego Ma[re]wicza roku 1795, w tymże roku dnia 26 Kwietnia grana na Teatrze Wileńskim, (b.m., b. r.); Estr., t. 22, s. 153.

${ }^{187}$ Wincenty Gawarecki, Oblężenie Płocka rycerskie drama z chorami, marszami. We III. aktach, z Dzieiów Oyczystych oryginalnie napisane przez... Wystawione na Teatrze Narodowym w Płocku dnia 20 Lipca 1817. roku, przez Artystów Dramatycznych pod Dyrekcya Jana Milewskiego, kosztem autora, druk. XX. Pijarów, Warszawa 1817, 1823; Estr., t. 8, s. 104.

${ }^{188}$ Wichert Jan (Wihert), Belizar Traiedia Przez Xiędza Iana De Wihert Kustosza Jnflantskiego w Piaciu Aktach Dnia 15. Grudnia Napisana Druk. Nadworney Jego Krol: Mości Y Prześ. Kom. Edu. Narod., (po 1787); Estr., t. 32, s. 427.

189 Jan Franciszek, Marmontel, Córka znaleziona dramat w 3 aktach, druk. Dufour, Warszawa 1779; Estr., t. 22, s. 183.

${ }^{190}$ Ludwik A. Dmuszewski, Łaska imperatora, Opera wystawiona pierwszy raz na Teatrze Narodowym Warszawskim dnia 11 marca 1814 r. Poezya Ludwika A. Dmuszewskiego, muzyka Karola Kurpińskiego, druk. Pijarów, Warszawa b. r., Estr., t. 4, s. 198.

${ }^{191}$ Omytka, komedya we dwóch aktach z francuzkiego przettomaczona, druk. P. Dufour, Warszawa 1778; Estr., t. 23, s. 352.

192 „Izys Polska. Dziennik umiejętności, wynalazków, kunsztów i rękodzieł, pośw. krajowemu przemysłowi tudzież potrzebie wiejskiego i miejskiego gospodarstwa", Warszawa 1820-1828; Estr., t. 11, s. 171.

${ }^{193}$ Julian Ursyn Niemcewicz, Samolub. Kom. w 5 a., reprezentowana na Teatrze Warszwskim pierwszy raz 22 grudnia 1811, druk. XX. Pijarów, Warszawa 1814; Estr., t.3, s. 227.

${ }^{194}$ August Kotzebue, Wolny mularz. Kom. w 1 a., tłum. K. Brodziński, Warszawa, nakład i druk. Zawadzkiego i Węckiego, 1819. August Kotzebue, Wolny mularz, wyd. bez druk.,Warszawa 1819 (wariant drugi); Estr., t. 19, s. 155.

${ }^{195}$ Julian Ursyn Niemcewicz, Giermkowie króla Jana. Kom. $w 1$ a., naśl. z franc. Dupaty i Dieulafoy (1789); albo Ludwik Emanuel Mercier Dupaty, Giermkowie króla Jana. Kom. w 1 a., J. U. Niemcewicz, Warszawa 1808; Estr., t. 3, s. 228.

${ }^{196}$ Henryk Beck, Gawet na księżycu, komedya w 3 aktach, z francuskiego języka na polski język przełożona przez Alojzego Żółkowskiego, 11 Stycznia 1805 r. przez Aktorów Polskich na Teatrze Warszawskim pierwszy raz grana, druk. W. Dąbrowskiego, Warszawa 1805; Estr. XIX, t. 2, s. 145.

${ }^{197}$ Jan Paweł Woronicz, Sybilla, poema w czterech pieśniach, Kraków 1831; Estr., t. 5, s. 161. 
[143] 1308 Powieści moralne panny Uncy tom czwarty ${ }^{198}$, sąd bezstronny iednej damy filozofki ${ }^{199}$ razem w półskórek oprawne kopiejek siedm i pół

[144] 1309 Dziennik Warszawski ${ }^{200}$ tom drugi do dwunastego w sześciu książkach w półskórek oprawne kopiejek czterdzieści pięć

[145] 1310 Światowid ${ }^{201}$ tom drugi, w półskórek oprawne kopiejek trzy

[146] 1311 Rozmaitości Warszawskie ${ }^{202}$ z roku 1821 i 1822 razem w półskórek oprawne kopiejek pięć

[147] 1312 Rozmaitości Warszawskie z roku [k.11] 1824, 1825, 1826 w półskórek oprawne kopiejek pięć

[148] 1313 Rozmaitości Warszawskie z roku 1828 w półskórek oprawne kopiejek pięć

[149] 1314 Rozmaitości Warszawskie z roku 1829 w półskórek oprawne kopiejek pięć

[150] 1315 Rozmaitości Warszawskie z roku 1830 w półskórek oprawne kopiejek pięć

[151] 1316 Rozmaitości Warszawskie z roku 1832 w półskórek oprawne kopiejek pięć

[152] 1317 Rozmaitości Warszawskie z roku 1838 w półskórek oprawne kopiejek pięć

[153] 1318 Rozmaitości Warszawskie z roku 1830 z kwartału pierwszego w półskórek oprawne kopiejek pięć

[154] 1319 Krótkie zebranie trzech praw początkowych natury, politycznego i narodowego ${ }^{203} \mathrm{~W}$ półskórek oprawne kopiejek trzy

[155] 1320 Życie Marszałków francuskich w safian oprawne kopiejek czterdzieści pięćc ${ }^{204}$

[156] 1321 Echo nr 13. z roku $1841^{205}$ pół kopiejki

${ }^{198}$ Uncy, Powieści moralne z różnych autorów przez pannę... na dopetnienie jakoby powieści Marmontela wybrane, a z francuskiego na język polski przez IMC NN przełożone, t. 1-4, druk. P. Dufoura, Warszawa 1779-1780.

${ }^{199}$ Klaud. Cypr. Abrassewin, Wszyscy bładza czyli sprawa z obydwóch stron niestuszna albo sąd oboiętny iedney damy filozofki w teraźnieyszych okolicznościach Jezuitow francuskich r. 1762 wydany a z francuzkiego przettumaczony w polskim ięzyku do druku podany od N. P., druk. Jana Fryderyka Bartels, Gdańsk 1766; Estr., t. 12, s. 9.

200 „Dziennik Warszawski” (miesięcznik), Warszawa 1825-1829; Estr., t. 3, s. 403.

${ }^{201}$ „Światowid, czyli zbiór najciekawszych powieści i artykułów tak tłumaczonych jak oryginalnych, nauce i zabawie poświęconych przez tegoczesnych autorów” (przy „Gazecie Warszawskiej”); Estr., t. 3, s. 476.

${ }^{202}$ „Rozmaitości”. (Dodatek do „Gazety Korespondenta Warszawskiego”), od 1824 r. tyt.: „Rozmaitości Warszawskie”, Warszawa 1818-1839; Estr., t. 3, s. 468.

${ }^{203}$ Krotkie Zebranie Trzech Praw Poczatkowych. To Jest: Prawa Natury, Politycznego i Narodów. z Roznych Autorow Wyięte, druk. Kazimierza Schlichtyna, Lwów 1780; Estr., t. 35, s. 171.

${ }^{204}$ Tomasz Dziekoński, Życie marszatków francuzkich z czasów Napoleona z rycinami rytemi przez najpierwszych artystów francuzkich podlug oryginalnych obrazów z galeryi Wérsalskiej, nakł. S. H. Merzbacha, druk. Maksymiliana Chmielewskiego, Warszawa 1841, 1842; Estr., t. 5, s. 303. ${ }^{205}$ „Echo. Tygodniowy dodatek do Gazety Warszawskiej”, Warszawa 1841; Estr., t. 3, s. 405. 
[157] 1322 Orzeł Biały ${ }^{206}$ tomów dziewięć w trzech księgach w półskórek oprawne kopiejek trzydzieści

[158] 1323 Tencza ${ }^{207}$ dziewięć tomów niekompletnych w pięciu książkach oprawne w półskórek kopiejek trzydzieści

[159] 1324 Tencza tom piąty w półskórek oprawne kopiejek pięć

[160] 1325 Tencza tom drugi w półskórek oprawne kopiejek trzy

[161] 1326 Zbiór Historyi Ludu Izraelskiego ${ }^{208}$ w półskórek oprawne kopiejek pięć [162] 1327 Nanci adelson i Salwini ${ }^{209}$ i rozrywki przyjemne i pożyteczne ${ }^{210}$ tomów dwa razem w półskórek oprawne kopiejek pięć

[k. 12] [163] 1328 Inkassy $^{211}$ tom drugi w półskórek oprawne kopiejek pięć [164] 1329 Klasztor powieśćc ${ }^{12}$, tom piąty w półskórek oprawny kopiejek trzy

[165] 1330 Awantura Amelii ${ }^{213}$ tom trzeci w półskórek oprawny kopiejek trzy

[166] 1331 Aspazya $^{214}$ tom drugi w półskórek oprawny kopiejek trzy

[167] 1332 Wiersze X. B. W. ${ }^{215}$ w półskórek oprawne kopiejek trzy

[168] 1333 Podróż Guliwera ${ }^{216}$ tom trzeci bez początku w półskórek oprawny kopiejek dwie

[169] 1334 Przyjaźń patriotyczna ${ }^{217}$ w półskórek oprawne kopiejek dwie

${ }^{206}$ Prawdopodobnie,,Orzeł Biały” (trzy razy tygodniowo), Warszawa 1819-1820; albo „Orzeł Biały. Dziennik polit.” (dwa razy tygodniowo), Warszawa 1830; albo „Orzeł Biały”, (dwa razy miesięcznie), Bruksela 1839-1848; Estr., t. 3, s. 442.

207 „Tęcza. Pismo dodatkowe do Gazety Warszawskiej poświęcone literaturze”, (miesięcznik), Warszawa 1838-1839 (Kontynuacja „Światowida”, potem pt. „Wieniec”); Estr., t. 3, s. 478.

${ }^{208}$ Claude Fleury, Zbiór historyi Ludu Izraelskiego y uwag nad nim politycznych. Z Xiag Pisma świętego Starego Zakonu wyięty Przez X. S. B. Scholarum Piarum, druk. XX. Schol. Piarum., Warszawa (b.r.); Estr., t. 16, s. 237.

${ }^{209}$ Franc.[iszek] Tomasz Maria d'Arnaud Baculard, Adelson i Salwini, historya angielska, Warszawa 1808; Estr., t. 1, s. 185.

210 „Rozrywki Przyjemne i Pożyteczne. Dziełko pośw. literaturze, poezji i romansom”, przez Konstantyna Majeranowskiego, (później „Flora Polska”), t. 1-9, Kraków 1826; Estr. XIX, t. 4, s. 130.

${ }^{211}$ Jan Franciszek Marmontel, Inkasy, czyli zniszczenie państwa Peru napisane przez (...) tlum. Stanisława Kłokockiego, t. 1-2, druk. Grölla, Warszawa 1781; Jan Franciszek Marmontel, Inkasy, Lwów 1794; Estr., t. 22, s. 183; Jan Franciszek Marmontel, Inkasy, ed. 2, druk. Zawadzkiej, Warszawa 1801 ; Estr., t. 3 , s. 72.

${ }^{212}$ Walter Scott, Klasztor, Powieść z angielskiego przełożona, t. 1-5, („Biblioteka Nowych Romansów”), druk. Stereotypowa, Warszawa 1830; Estr., t. 4, s. 269.

${ }^{213}$ Mar[ia] Joanna, Laboras de Mézierès Riccoboni, Awantura Amalii przez Henryka Fieldinga wyjęta z dziet (...), Warszawa 1791; toż, Supraśl 1787-1788; Estr., t. 26, s. 298.

${ }^{214}$ Cnota $w$ drodze do szczęscia czyli Aspazya. Przypadki, angielskie tłumaczenie W. K***, t. 1-2, P. Dufour, Warszawa 1787; Estr., t. 14, s. 309; albo: Wincenty Kamieński, Cnota w drodze do szczęścia czyli Aspazya. Przypadki angielskie. Tlumaczenie W. K. t. 1-2, edycya nowa, druk. Tomasza Le Brun, Sukcessora Piotra Dufour, Warszawa 1803; Estr., t. 14 (II. ed.), s. 60.

${ }^{215}$ [Ignacy Krasicki], Wiersze X.B.W., nakładem i drukiem Mich. Grölla, Warszawa 1784.

${ }^{216}$ Jan Swift, Podróże Kapitana Gulliwera w Rozne Kraie Dalekie w Języku Angielskim napisane, t. 1-2, Supraśl 1784, wyd. 2, druk. Grebla, Kraków 1804. Prawdopodobnie była jeszcze edycja w 1787 r.; Estr., t. 19, s. 99.

${ }^{217}$ Adolf Kamieński, Przyjaźń patriotyczna, w którey się podaja sposoby niezawodne do uczynienia ludzi cnotliwymi i lepszymi obywatelami, nakł. M. Grölla, Warszawa 1772; Estr., t. 19, s. 75. 
[170] 1335 Nauka położnic ${ }^{218}$ w półskórek oprawne kopiejek trzy

[171] 1336 Obowiązki damy chrześcijańskiej ${ }^{219} \mathrm{~W}$ półskórek oprawne jedna kopiejka [172] 1337 Adyna Romans ${ }^{220}$ w półskórek oprawne kopiejek trzy

[173] 1338 Kalendarzyk polityczny na rok $1844^{221} \mathrm{~W}$ safian oprawny z futerałem kopiejek trzy

[174] 1339 Memoires dela societe Royale de antiquaires du nord ${ }^{222} \mathrm{w}$ papier oprawne kopiejek pięć

[175] 1340 Kodex paenalis pro Galicia occidentali223 pół kopiejki

[176] 1341 Uwagi nad uwagami o dziesięcinach ${ }^{224}$ pół kopiejki

[177] 1342 Uwagi nad uwagami o dziesięcinach pół kopiejki

[178] 1343 Dokumenta do spraw dziesięcinnych w Polsce ${ }^{225}$ pół kopiejki

[179] 1344 Opusculum impedimenta quedam sanitatis communia ${ }^{226} \mathrm{w}$ papier oprawne pół kopiejki

${ }^{218}$ Prawdopodobnie: Jędrzej Glaber Cobylinus (z Kobylina), Nauka położnic ratowania y leczenia, przez mistrza Andrzeia z Kobylina napisana y nowo wydana, druk. Andrzeja Piotrkowczyka, 1589; Estr., t. 17, s. 156; albo Glaber Jędrzej Cobylinus (z Kobylina), Nauka położnic ratowania y leczenia, przez mistrza Andrzeia z Kobylina napisana y nowo wydana, druk. Andrzeja Piotrkowczyka, 1618; Estr., t. 17, s. 156; albo Augier Du Fot An. Amable, Nauka położnicza przez pytania y odpowiedzi po francuzku napisana a teraz wyłożona po polsku przez Józefa Berger de Lonchamps ucznia medycyny, nauk wyzwolonych i filozofii doktora, korrepetytora anatomii w Szkole głównej W. X. L., Druk. Akad., Wilno 1789; Estr., t. 12, s. 263.

${ }^{219}$ Obowiązi Damy chrześciańskiey, druk. M. Gröll, Warszawa 1769, 1779; Estr., t. 23, s. 225.

220 Franciszek Jan d'Villemain Abancourt, Adina czyli pasterka pyreneyska i innch kilka romansów napisana po francuzku przez (...), a po polsku wytożona przez F. Zaleskiego, druk. Ragoczy, Warszawa 1808; Estr., t. 1, s. 3.

${ }^{221}$ Prawdopodobnie: Kalendarzyk polityczny, wydany przez Fr. Radziszewskiego, Warszawa (1829-1848) lub Kalendarzyk Polityczny krakowski na rok 1844. Rok pierwszy, Druk. Uniwersytecka, nakł. J. Cypcera, Kraków (1843); Estr., t. 3, s. 367.

${ }^{222}$ Mémoires de la Société royale des antiquaires du nord, 1840-1844. Copenhague,Secrétariat de la Société, 1844, https://www.worldcat.org/title/memoires-de-la-societe-royale-des-antiquairesdu-nord-1840-1844/oclc/15503221 (dostęp: 10.11.2019).

${ }^{223}$ Codex poenalis pro Galicia Occidentali, typis Josephi Hraschanzky, Viennae 1796; Estr., t. 14 , s. 314 .

${ }^{224}$ Uwagi nad uwagami o dziesięcinach, druk. Tomasza Le Brun, Warszawa 1803; Estr., t. 4, s. 626 .

225 Józef Olechowski, Dokumenta do spraw dziesięcinnych w Polszcze. Si non sunt validae dotes et privilegia majorum et antecessorum nostrorum ecclesiis collata, cujus erunt firmitatis illa, aliis ordinibus, sub paribus signis, pari atramento et pelle concessa? Sigismundus I ad Consiliarios Prussiae, vol. I, fol. 484, Kraków 1779; albo Józef Olechowski, Dokumenta do spraw dziesięcinnych w Polszcze powtore do druku podane, przez W. Jmci Xiędza Jana Polanowskiego Proboszcza Rzepińskiego, druk. Bractwa Swiętey Troycy, Lwów 1781; albo Józef Olechowski, Dokumenta, druk. XX. Trynitarzów, Lublin 1788; Estr., t. 19, s. 319-320.

${ }^{226}$ [Jan Nepomucen Antoni Hermann], Nepomuceni Hermani, Opusculum impedimenta quaedam sanitatis comunia exhibens, Typis S. R. M. in Collegio PP. Trynitariorum, Lublini 1782; Estr., t. 18, s. 156. 
[k. 13] [180] 1345 Retoryka Instytucio ${ }^{227}$ w skórę oprawne kopiejka jedna [181] 1346 Abrege Raisonne de Historye universalle sacre et profane ${ }^{228}$ w skóre oprawne kopiejka jedna 1

[182] 1347 Opisanie Królestwa Portugaliii ${ }^{229}$ w papier oprawne pół kopiejki

[183] 1348 Gramatyka łacińska bez tytułu w papier oprawne kopiejki pół

[184] 1349 Filozof bez religii ${ }^{230} \mathrm{w}$ półskórek oprawne tomów dwa kopiejka jedna i pó1

[185] 1350 Rudimenta Geographica ${ }^{231}$ w skórę oprawne kopiejka jedna

[186] 1351 Geografia bez początku w papier oprawne pół kopiejki

[187] 1352 Epigramata Deceyusa ausoniusza przez Minasowicza ${ }^{232}$ w półskórek oprawne kopiejek dwie

\section{Tytuł XXXXI Książki duchowne}

[188] 1353 Kazania o nieśmiertelności dusz ${ }^{233}$ w papier oprawne kopiejka jedna [189] $1354 \mathrm{O}$ władzy duchowney ${ }^{234} \mathrm{w}$ papier oprawne kopiejka jedna i pół [190] 1355 Woyna duchowna ${ }^{235}$ w półskórek oprawne kopiejek trzy

${ }^{227}$ Prawdopodobnie jedno z wydań podręcznika: Marcin Waleszyński, Rhetorica Institutio, IV Libris, Typis eiusdem Universitatis, Cracoviae 1722; Marcin Waleszyński, Rhetorica Institutio V Libris comprehensa, ed. secunda, Typis Collegii Majoris Universitatis, Cracoviae 1752; Estr., t. 32, s. 170.

${ }^{228}$ Perrin de Chavanette, abbé, Abrégé portatif de l'histoire universelle, sacrée et profane, pour l'instruction de la jeunesse par, vol. 1-3, Saugrain le jeune, Paris 1778, https://catalogue.bnf.fr/ ark:/12148/cb393610687 (dostęp: 10.11.2019).

${ }^{229}$ Aubert René Vertot, Opisanie Krolestwa Portugalii Y Historya Przednieysze w sobie Państwá tego dzieie Y Kilku wiekow rewolucye Zamykaiaca Z rożnych pisarzow Mianowicie z Sławnego Francuza Jmieniem L'Abbe de Vertot. Zebrana Y Dla pożytku Národu Polskiego, Druk. Soc. Jesu, Lublin 1754; Estr., t. 32, s. 391.

${ }^{230}$ Jakub Vernet, Filozof bez Religii uważany w towarzystwie. Przez W. JX. X.(awerego) B.(ohusza) P.(ratata) Kapituly) W. X. L.(itewskiego), t. 1-2, Druk. Akademicka, Wilno 1786; Estr., t. 32 , s. 379 .

${ }^{231}$ Jedno z wydań: Rudimenta Geographica sive brevis facilisque Methodus Juventutem Orthodoxam notitia Geographica imbuendi. Pro Gymnasiis S. J. Auctore ejusdem Societatis Sacerdote. Opusculum sextum. Cum Fac. Sup. Juxta Exemplar Wratislav. Reimpressa, typis Coll. Soc. Jesu, Brunsbergae 1742. Inne wydania: Calissii 1745, Leopoli 1746, Calissii 1753, Lublini 1761; Estr., t. 26, s. 457.

${ }^{232}$ D.M. Ausonius, Epigramaty, nagrobki bohatyrów greckich i trojańskich; Edylie, przekładania J. E. Minasowicza, druk. Mitzler, Warszawa 1765; D.M. Ausonius, Epigrammata, nagrobki i edyllia wybrane, przekt. J. E. Minasowicza, Warszawa 1765; Estr., t. 1, s. 305.

${ }^{233}$ Prawdopodobnie: Andrzej Filipecki, O nieśmiertelności duszy ludzkiey przeciwko teraznieyszym libertynom, kazania w kościele katedr. metropolit. Lwowskiey na niedziele adwentowe przez X. Andrzeia Filipeckiego Soc: Jesu w teyże katedrze kaznodzieię Ordynariusza miane, druk. Akademickiey Collegii Soc. Jesu, Lwów 1769; Estr., t. 16, s. 217.

${ }^{234}$ Adalbert (Wojciech) Skarszewski Leszcyc, O władzy duchownej przez Autora Pisma o matżeństwie b.m. i b.r. (druk. XX. Misjonarzy, Warszawa 1820); Estr., t. 4, s. 255.

${ }^{235}$ Jedno z wydań: Laurenti Scupoli, Woyna duchowna W.O Laurentiusa Skupuli, Zakonu Teatyńskiego (...) zalecona przez Deotyma Nerserowicza Penitencjarza do Polski sprowadzona, Zamość 1683; Woyna duchowna albo nauka do doskonałego zwycięstwa samego siebie prowadzaca po 
[191] 1356 Boga nieśmiertelnego Święta Historya ${ }^{236}$ w papier oprawne kopiejek dziesięć

[192] 1357 Officia propria sanctorum patronum ${ }^{237}$ W skórę oprawne kopiejek piętnaście

[193] 1358 Sposób przestawania z Bogiem ${ }^{238} \mathrm{w}$ półskórek oprawne kopiejek trzy

[194] 1359 Dictionaire Historique [k. 14] de la Biblie ${ }^{239}$ tom 6 w półskórek oprawne rubel srebrem jeden

[195] 1360 Wiadomość historyczna o cudownem medalu panny Maryi ${ }^{240} \mathrm{w}$ papier oprawne kopiejek dwie

całym chrześcijaństwie w różnych językach wydana od ks. Deodata Nerserowicza (...) na polski język przełożona, druk. Soc. Jesu, Lublin 1746. Inne wydania: Wilno 1759, Lublin 1761, Berdyczów 1767, Połock 1792, Przemyśl 1797. Łącznie ukazało się 9 wydań do końca XVIII w.; Estr., t. 27, s. 319. Ponadto J. Casteniza, Pugna spiritualis, 1644; albo Rozbrat (grzesznika ze światem), Typis Academiae Posnaniensis, 1719; Estr., t. 33, s. 215.

${ }^{236}$ Ksawery Orłowski, Boga nieśmiertelnego w śmiertelnej ludzkiej naturze cierpiacego historia święta, wyjątkami nauki obyczajowej z pisma św. i Ojców kościoła objaśniona dla użytku chrześcijan prawowiernych z łacińskiego na język polski przettumaczona, druk XX. Pijarów, Warszawa 1837; Estr., t. 3, s. 315.

${ }^{237}$ Oficja własne patronów - formularze liturgii godzin używane w dniach obchodów własnych patronów; związane z kultem świętych, rozpowszechnione w skutek rozwoju sztuki drukarskiej. Teksty of. zawarte są w księgach liturgicznych oraz w dodatkach wydawane za aprobatą stolicy apostolskiej. W Polsce w 1641 r. ukazały się: Officia propria SS. patronorum Regni Poloniae et Sueciae, Wł. 1641; Krzysztof Stola, Oficja własne patronów, w: Encyklopedia katolicka, t. 14, red. E Gigilewicz, Lublin 2010, kol. 405-406. Ponadto Estr. notuje m.in. Officia propria SS. patronum Regni Sveciae ex vetustis breviariis eiusdem Regni deprompta: Ad instantiam Sermi Sigismundi III Sueciae et Poloniae Regis, a sac. rituum congregatione, auctoritate apostolica, recognita et approbata, atq; omnibus tam in dicto Sueciae quam etiam Poloniae regno habitantibus concessa ut libere et licite translatis vel omissis aliis officiis, quae eadem die occurrunt, recitari possint et valeant, in officina Plantiniana Baltasaris Moreti, Antverpiae 1631; albo Officia propria Patronorum Regni Poloniae olim edita et juxta Ritum Breviarii monastici pro omnibus sub Regula S. P. Benedicti militantibus accomodata nunc denuo ob defectum per RR. PP. Eremitas Camaldulenses Montis Argentini reimpressa et aucta, in typographia seminarii acad., Cracoviae 1770; albo Officia propria sanctorum patronum Sacri Ordinis Divi Benedicti ex recenti Breviario Benedictino desumpta ... typis mandata A.D. 1681 (B.m.w.); Estr., t. 23, s. 275.

${ }^{238}$ Sposób przestawania z Bogiem czyli nauka pokazuiąca łatwość każdego stanu i kondycyi człowiekowi mimo swoich zabaw myślenia o Bogu. Dzieło to w francuskim ięzyku napisane, dla gruntownych dowodów wielce pożyteczne na polski ięzyk przetlumaczone, do druku podane roku 1780, druk. Kazim. Szlichtyna, Lwów [1780]; Sposób przestawania z Bogiem, druk. XX. Missionarzów, Warszawa 1780; Estr., t. 29, s. 131.

${ }^{239}$ Augustin Dom Calmet, Dictionnaire historique, critique, chronologique, géographique et littéral de la Bible, par le (...), t. 1-4, chez Marc-Michel Bousquet, Genève 1730 i inne wydania, https://gallica.bnf.fr/ark:/12148/btv1b8626560z/f2.image (dostęp: 10.11.2019).

${ }^{240} \mathrm{O}$. Aladel, Wiadomość historyczna o początku i skutkach nowego medalu wybitego na cześć Niep. Pocz. N. P. M. a powszechnie znanego pod imieniem medal cudowny. Z dołaczona przy końcu nowenna przez Xiędza M., thum. z franc., Warszawa 1838; Estr. XIX., t. 1, s. 69. 
[196] 1361 Treść nauki chrześcijańskiej ${ }^{241}$ w dwóch egzemplarzach pół kopiejki [197] 1362 Fundacya zakonna Xięży kapucynów w Warszawie ${ }^{242}$ kopiejka jedna i pół

[198] 1363 Nauka o Jubileuszu ${ }^{243}$ w dwóch exemplarzach kopiejka jedna

[199] 1364 Chwała Męczennika Świętego Jana Nepomucena ${ }^{244}$ w papier oprawne pół kopiejki

[200] 1365 Obrona Chrystianizmu ${ }^{245}$ tom trzeci i czwarty w półskórek oprawne kopiejek pięć

[201] 1366 Podział Historyi Świętej246 tomów dwa w półskórek oprawne kopiejek pięć

[202] 1367 Książka do Nabożeństwa przez Dunina ${ }^{247}$ w safian oprawna z futerałem kopiejek czterdzieści pięć

${ }^{241}$ Jest: Robert Franc. Bellarmin, Krótki zbiór nauki chrześciańskiej przez X. Bellarmina, przekład z łacińskiego przez Kaspra Sawickiego, Wilno 1606; albo [Grzegorz Piramowicz?] Zbior nauki chrześcijańskiej, 1784; albo Onufry Kopczyński, Zbiór Nauki I Chrześcijańskiéj i II Obyczajowej, Warszawa 1786. Ukazało się 15 edycji do 1845 r., ostatnie wyd. Warszawa 1858; Estr., t. 20, s. 74; Estr. XIX, t. 17, s. 419-420.

${ }^{242}$ Michał Baliński, Fundacya zakonu i kościoła XX. Kapucynów w Warszawie. Pismo umieszczone w Roczniku religijnym ,Alleluja”, druk. przy ul. Rymarskiej, Warszawa 1840; Michał Baliński, Fundacya, nakł. Sennewalda, (Warszawa) 1843; Estr. XIX, t. 2, s. 39.

${ }^{243}$ Antoni Malinowski, Nauka o Jubileuszu z przydatkiem różnych modlitw, wydana przez X. S. T. L. Missionarza Zakonu Kaznodzieyskiego, druk. XX. Bazylianow, Wilno 1776; Estr., t. 22, s. 95.

${ }^{244}$ Prawdopodobnie: Chwała Bogu w Troycy Świętey jedynemu ze sława S. Jana Nepomucena złaczona, druk. Akad. S. Jesu, 1747; Estr. t. 14, s. 231; albo: Forteca ręka boska wystawiona to jest życie, smierć i czcenie S. Jana Nepomucena męczennika niegdyś z łacińskiego na język polski przethumaczone i i w Krakowie w R.P. 1716 drukowane a teraz powtórnie do druku podane R. P. 1736, Wilno; Estr., t. 18, s. 437.

${ }^{245}$ Dionizy Frayssinous (de) ks., Obrona Chrystyianizmu przez X. (...), biskupa hermopolitańskiego, ministra spraw religiynych, iednego z czterdziestu członków Akademii paryzkiéy, para Francyi, piérwszego jałmużnika przy królu, przektad Modesta Watta Kosickiego doktora filozofii (dokończony, zaś zaczęty przez Józefa Lipińskiego). (Biblioteka Chrześcijańska), t. 1-4, Druk. Szkolna, Warszawa (t. 1-3) 1827, (t. 4) 1828; Dionizy Frayssinous (de) ks., Obrona, wyd. II poprawione, t. 1-4, Warszawa 1828; Estr. XIX, t.7, s. 227.

${ }^{246}$ Claude Fleury, Podziat Historyi Swiętey zawieraiacy w sobie cztery rodzaie rzadu ludu Bożego przez Ant. Apolskiego, t. 1 Łowicz 1782; Estr, t. 16, s. 237.

${ }^{247}$ Jedno z wydań popularnego modlitewnika: Marcin Dunin Sulgustowski, Książka do nabożeństwa, z polecenia Najprzewielebniejszego ś. p. arcybiskupa Dunina wyjęta z świeżo wyszłej książki dla wszystkich katolików szczególniej zaś dla wygody katolików archidyecezyi poznańskiej i gnieźnieńskiej, dla kobiet, Leszno, druk. Ernesta Güntera, Gniezno 1842; Marcin Dunin Sulgustowski, Ksiażka do nabożeństwa, z polecenia Najprzewielebniejszego ś. p. arcybiskupa Dunina wyjęta z świeżo wyszłej książki dla wszystkich katolików szczególniej zaś dla wygody katolików archidyecezyi poznańskiej i gnieźnieńskiej, nakł. i druk. W. Stefańskiego, Poznań 1844. Były cztery wydania do 1845 r., w tym oddzielne wydania dla kobiet i mężczyzn. Wielokrotnie wznawiane w różnych wersjach do pocz. XX w.; Estr. XIX, t. 5, s. 233, https://katalogi.bn.org.pl/discovery/search?query=any,contains,Dunin\%20Sulgustowski\&tab=LibraryCatalog\&vid=48OMNIS_NLOP:48OMNIS_NLOP\&lang=pl\&offset=0. (dostęp: 10.11.2019). 
[203] 1368 Directorium officis divini $^{248}$ na rok 1844 w materie karmazynową oprawna w futerale kopiejka jedna

[204] 1369 O rozmyślaniu męki Jezusowej249 część druga w półskórek oprawne kopiejki pół

[205] 1370 Modlitwa dla chorych ${ }^{250} \mathrm{w}$ papier oprawne pół kopiejki

[206] 1371 Człowiek Chrześcijański251 w półskórek oprawne kopiejek dwie

[207] 1372 Jasna pochodnia Swiętego Franciszka Salezyusza ${ }^{252}$ w półskórek oprawne pół kopiejki

[208] 1373 Mądrości i Męztwo Swiętej Tekli253 [k.15] w półskórek oprawne kopiejka jedna

[209] 1374 Katechizm filozoficzny ${ }^{254}$ tomów dwa w papier oprawne kopiejek trzy [210] 1375 Rok miłości Boskiej ${ }^{255} \mathrm{w}$ skórę oprawne kopiejek trzy

[211] 1376 Nowy Testament przez Wujka ${ }^{256}$ w skórę oprawne kopiejek piętnaście

${ }^{248}$ Directorium officis divini, rubrycela, wydawnictwo kościoła katolickiego zawierające szczegółowy opis roku liturgicznego; Mariusz Konieczny, Rubrycella, w: Encyklopedia katolicka, t. 17, red. E. Gigilewicz, Lublin 2012, kol. 513-514. Liczne edycje podaje Estr., t. 15, s. 213.

${ }^{249}$ Krótka [nauka] o rozmyślaniu, którego Zakon Soc. Jesu zażywa wedle nauki S. Ignacego Patryarchy swojego, druk. Akad. S. J., Wilno 1772; Estr., t. 23, s. 60.

${ }^{250}$ Modlitwa dla chorych, z przydatkiem aktów miłości Boga i Jezusa w najświętszym Sakramencie utajonego, Warszawa 1806; Estr., t. 3, s. 149.

${ }^{251}$ Robert Bellarmin, Piętnaście stopni, Po ktorych człowiek, zwłasczá Krześciański, upatruiąc Pana Boga w stworzeniu rozmaitym, przychodźi do wielkiey znáiomośći iego. Opisáne przez Roberta Kardinała Bellarmina Societatis Iesu. Do Jasnie Oświeconego y Wielebnego Kardynała Piotra Aldobrandina Dozorce dochodów Kościoła Rzymskiego. Przełożone z Łacińskiego ná Polskie Przez X. Kaspra Sawickiego Societatis Iesu, Druk. Franciszka Cezarego, Kraków 1616; Estr., t. 12, s. 448.

${ }^{252}$ Ludwik Abelli [Louis Abelly], Jasna pochodnia albo żywot S. Franciszka Salezyusza biskupa y xiążęcia Genewy przez jednego Schol. Piarum kapłana polskim stylem darowany, druk. Elert., Warszawa 1667; Estr., t. 16, s. 4.

${ }^{253}$ Prawdopodobnie: Jakob Cudnicki, Nabożeństwo do Ś. Tekli panny y pierwszey męczenniczki dla wygody wszystkich nabożnych przez X. Jakuba Cudnickiego K. P. D. P. G. nowo utożone y za pozwoleniem zwierzchności, do druku podane roku pańskiego 1788, druk. prymasa Arcy-Biskupa Gnieźnieńskiego, Łowicz (1788); Estr., t. 14, s. 459.

${ }^{254}$ Franciszek Ksawery Feller S.J., Katechizm Filozoficzny czyli Zbiór dowodów slużących na obronę Wiary Chrześciańskiey przeciwko nieprzyjaciołom jey. Dzieło pożyteczne dla tych, którzy chca uniknać zarazy od niedowiarków teraźnieyszych, a mianowicie dla Duchownych, którym z obowiązku należy drogi skład Wiary S. w całości dochować. W języku francuzkim napisane przez X. Flexier de Reval tlumaczone przez X. Th. Waluszewicza, t. 1-2, Druk. Akad., Wilno 1784; Estr., t. 16 , s. 190.

${ }^{255}$ Jan Chrzcic. Eliasz Avrillon, Rok miłości Boskiey z pieni świętych na każdy dzień roku przez affekta rozłożony, przez Wielebnego Oyca Jana Eliasza zakonu S. Franciszka de Paula po trzeci raz do druku w roku pańskim 1719 podany, a teraz z francuskiego języka na polski przez zakonnice Nawiedzenia Nayświętszey Maryi Panny klasztoru Krakowskiego przettumaczony, druk. Seminarium biskupiego akademickiego, Kraków [1767], Estr., t. 12, s. 315.

${ }^{256}$ Jedno z wydań: Nowy Testament Pana Naszego Jezusa Chrystusa, przed. Jakub Wujek, S.J., druk. Piotrkowczyka, Kraków 1593, 1594. Kolejne przedruki: 1605, 1617, 1621, 1647 i później; Estr., t. 33, s. 379. 
[212] 1377 Wybór kazań Xiędza Wijatora Piotrowskiego ${ }^{257}$ tomów cztery w trzech księgach w pólskórek oprawne kopiejek piętnaście

[213] 1378 Canon Missae cum prefacionibus ${ }^{258}$ W skórę oprawne in folio z futerałem rubel srebrny jeden

[214] 1379 Canon Missae pontifikalis ${ }^{259}$ w skórę oprawne in folio z futerałem rubel srebrny jeden

[215] 1380 Ceremoniale Episcoporum ${ }^{260} \mathrm{~W}$ safian oprawne rubel srebrny jeden

[216] 1381 Pontificale Romanum ${ }^{261}$ z roku 1627 in folio w skórę z futerałem oprawne rubel srebrny jeden

[217] 1382 Pontificale Romanum z roku $1769^{262} \mathrm{~W}$ safian oprawne rubel srebrny jeden

[218] 1383 Breviarum Romanum ${ }^{263}$ z roku 1787 w skórę oprawne z futerałem skórzanym kopiejek siedemdziesiąt pięć

${ }^{257}$ Piotrowski Wiator OFMCap. (1769-1835) kaznodzieja, autor m.in. Wybór kazań niedzielnych, światecznych i przygodnych (t.1-4), Warszawa 1840.

${ }^{258}$ Mszał, księga liturgiczna, zawierająca teksty stałych i zmiennych części mszy. Pierwszy mszał obejmujący całość liturgii ogłosił Pius V w 1570 r. Jedno z wydań: Canon Missae cum Prefationibus et Rubro (b.m.w., b.r.); Estr., t. 3, s. 17; albo m.in. Canon Missae cum prefationibus \& alijs nonnullis quae in ea fere communiter dicuntur. Additae sunt praeparationes ad Missam, et orationes, quae ab episcopis (...) sacerdotibus dici solent (...) apud Cieras, Venetiis 1630, https://opac.bibliothecaterraesanctae.org/cgi-bin/koha/opac-detail.pl?biblionumber $=1042$ 05\&query_desc $=$ an $\% 3$ A $4228 \% 20$ and $\% 20$ itype $\% 3$ AAB $\% 20$ and $\% 20 a u \% 3$ AChiesa $\% 20$ Cattolica (dostęp: 10.11.2019).

${ }^{259}$ Księga liturgiczna, zawierająca reguły uroczystej mszy.

${ }^{260}$ Ceremoniasz (łac. ceremoniale), zbiór ceremonii, księga z przepisami uroczystego sprawowania liturgii w Kościele rzymsko-katolickim, stanowi dopełnienie mszału, brewiarza, pontyfikatu i rytuału. Rozróżnia się c. papieski, biskupi i parafialny; M. Pisarzak, Ceremoniat, w: Encyklopedia katolicka, t.3, red. R. Łukaszyk, Lublin 1985, kol. 7-9.

${ }^{261}$ Pontyfikał, księga liturgiczna zawierająca opis i teksty sprawowanych przez biskupa liturgicznych czynności, wielokrotnie modyfikowana w XVI w. Pierwsza drukowana edycja pontyfikału rzymskiego ukazała się w 1485 r.; M. Maciukiewicz, Pontyfikat, w: Encyklopedia katolicka, t. 15, kol. 1409-1410. Jedno z wydań, m.in. Pontificale Romanum Clementis VIII Pont. Max. iussu restitutum atque editum. Nunc primum Typis Plantinianis emendatius recusum, Ex Officina. Plantiniana, Apud Balthasarem Moretum et Viduam Ioannis Moreti et Io. Meursium, Antverpiae, https://obc. opole.pl/dlibra/publication/7550/edition/6486?language=pl (dostęp: 10.11.2019); https://www. worldcat.org/title/pontificale-romanum-clementis-viii-pont-max-iussu-restitutum-atque-editum/ oclc/059212510 (dostęp: 10.11.2019).

${ }^{262}$ Jedno z wydań, m.in. Pontificale romanum Clementis VIII et Urbani VIII jussu editum (...) a Benedicto XIV, Venetiis, Typographia Balleoniana, 1769; Pontificale Romanum (...) a (...) Benedicto XIV. recognitum \& castigatum, etc., ex Typographia Balleoniana, Venetiis 1769, https://www. worldcat.org/title/pontificale-romanum-a-benedicto-xiv-recognitum-castigatum-etc/oclc/776908591\&referer=brief_results (dostęp: 10.11.2019).

${ }^{263}$ Brewiarz (Brevarium), księga liturgiczna kościoła rzymskiego zawierająca teksty modlitwy godzin kanonicznych (officium divinum) przeznaczona dla duchowieństwa z wyższymi święceniami. Brewiarz rzymski - ujednolicony tekst dla całego kościoła zach. powstał w 1568 r., przechodził liczne modyfikacje. Oficjalne teksty wydawane były w Rzymie, Wenecji, Moguncji, Strasburgu. 
[219] 1384 Breviarum Romanum z tegoż roku w skórę oprawne w futerale skórzanem rubel srebrny jeden

[220] 1385 Breviarum Romanum z roku 1729 w mniejszym formacie w oprawie zniszczonej kopiejek pięćdziesiąt

\section{REFERENCES / BIBLIOGRAFIA}

\section{Źródła}

Archiwum Państwowe w Lublinie (APL)

Akta Serafina Konwickiego notariusza w Lublinie, 1845, akt 634 (43).

Biblioteka Wojewódzka im. H. Łopacińskiego w Lublinie.

syg. 515, Papiery po biskupie Lubelskim Wojakowskim, Rks r.1802, 1843. Opis życia, k. 33-34.

Tabella Miast, Wsi, Osad Królestwa Polskiego z wyrażeniem ich położenia i ludności alfabetycznie ułożona w Biórze Kommisji Spraw Wewnętrznych i Policyi, Warszawa 1827.

\section{Opracowania}

Bazydło Janusz, Barruel Augustin, w: Encyklopedia katolicka, t. 2, red. F. Gryglewicz, R. Łukaszyk, Z. Sułowski, Lublin 1995, kol. 64.

Bieńkowska Barbara, Inwentarze księgozbiorów prywatnych jako źródło do badań nad dziejami czytelnictwa, „Studia o Książce”,18 (1989) s. 65-75.

Danielewski Wojciech, Brewiarz, w: Encyklopedia katolicka, t. 2, red. F. Gryglewicz, R. Łukaszyk, Z. Sułkowski, Lublin 1995, kol. 1064-1071.

Daniluk Mirosław, Feller François Xavier, w: Encyklopedia katolicka, t. 5, red. L. Bieńkowski i in., Lublin 1989, kol. 112-113.

Dymmel Anna, Ksieggozbiory prywatne ziemiaństwa lubelskiego w połowie XIX wieku (w świetle akt notarialnych Serafina Konwickiego), „Res Historica”, 13 (2002) s. 243255.

Dymmel Anna, Wartość lubelskich akt notarialnych jako źródla do badań prywatnych księgozbiorów duchowieństwa w pierwszej połowie XIX wieku, „Archiwa, Biblioteki i Muzea Kościelne”, 110 (2018) s. 145-166. https://doi.org/10.31743/abmk.2018.110.09

Estreicher Karol, Bibliografia polska, t. 1-34, Kraków 1870-2000.

Estreicher Karol, Bibliografia polska XIX. stulecia, t. 1-17, wyd. 2, Kraków 1959-2000.

Gerber Rafał, Studenci Uniwersytetu Warszawskiego 1808-1831. Stownik Biograficzny, Wrocław 1977.

Konieczny Mariusz, Rubrycella, w: Encyklopedia katolicka, t. 17, red. E. Gigilewicz, Lublin 2012, kol. 513-514.

Kozińska-Chachaj Joanna, Księgozbiory ziemiańskie na Lubelszczyźnie w XIX i XX w., „Bibliotekarz Lubelski”, 47 (2004) s. 61-74.

Kukulski Zygmunt, Towarzystwo Przyjaciół Nauk w Lublinie na tle epoki (1815-1830), Lublin 1939.

Norymberdze, Krakowie; W. Danielewski, Brewiarz, w: Encyklopedia katolicka, t. 2, red. F. Gryglewicz, Lublin 1995, kol. 1064-1071. 
Maciukiewicz Maciej, Pontyfikat, w: Encyklopedia katolicka, t. 15, red. E. Gigilewicz, Lublin 2011, kol. 1409-1410.

Modzelewska Bożena, Wójcik Walenty, Fleury Claude, w: Encyklopedia katolicka, t. 5, red. L. Bieńkowski i in., Lublin 1989, kol. 324-325.

Nitecki Piotr, Biskupi kościoła w Polsce w latach 965-1999. Słownik biograficzny, Warszawa 2000, kol. 487-488.

Olszewski Daniel, Książka religijna na terenie Królestwa Polskiego w XIX wieku, „Rocznik Świętokrzyski”, 16 (1989) s. 147-173.

O[strołęcki] Stanisław, Cmentarz parafialny rzymsko-katolicki w Lublinie, Warszawa 1902.

Pisarzak Marian, Ceremoniat, w: Encyklopedia katolicka, t.3, red. R. Łukaszyk, Lublin 1985, kol. 7-9.

Prejs Roland, Piotrowski Wiator, w: Encyklopedia katolicka, t. 15, red. E. Gigilewicz, Lublin 2011, kol. 704.

Sadurski Ireneusz, Biskup sufragan lubelski Mateusz Maurycy Wojakowski wobec powstania listopadowego, w: Powstanie Listopadowe na Lubelszczyźnie. Wydarzenia, ludzie, źródta, red. A. Barańska, J. Skarbek, Lublin-Oświęcim 2013, s. 54-76.

Sinko Zofia, Z zagadnień recepcji ,Sądu Ostatecznego” $i$ „,Myśli nocnych” Edwarda Younga, „Pamiętnik Literacki”, 65 (1974) z. 2 s. 93-155.

Skarbek Jan, Udziat duchowieństwa lubelskiego w Powstaniu Listopadowym, „Roczniki Humanistyczne", 17 (1969) z. 2, s. 83-93.

Słownik geograficzny Królestwa Polskiego i innych krajów słowiańskich, nakł. Filipa Sulimierskiego i Władysława Walewskiego, Warszawa 1880-1914.

Smoleński Stanisław, Abelly Louis, w: Encyklopedia katolicka, t. 1, red. F. Gryglewicz, R. Łukaszyk, Z. Sułowski, Lublin 1985, kol. 13.

Stępniak Halina, Spotkanie naukowe „Biskup sufragan lubelski Mateusz M. Wojakowski w powstaniu 1830-1831”, 20.11.2012, https://garbow.pl/aktualnosci/n,62428, spotkanie-naukowe-biskup-sufragan-lubelski-mateusz-m-wojakowski-w-powstaniu-1830-1831.html (dostęp: 01.12.2019).

Stola Krzysztof, Oficja własne patronów, w: Encyklopedia katolicka, t. 14, red. E. Gigilewicz, Lublin 2010, kol. 405-406.

Szady Joanna, Inwentarz księgozbiorów parafialnych z drugiej połowy XVIII wieku - nowa metoda edycji, ,Textus et Studia”, 1 (2016) nr 5, s. 78-90, doi:10.19265/TES.2016.01577.

Szczurowski Rafał, Oświecenie i kontroświecenie czasów Królestwa Polskiego. Polemika o. Karola Surowieckiego z ministrem Stanisławem Kostka Potockim, „Folia Historica Cracoviensia", 23 (2017) nr 2, s. 406-426.

Wasilewski Jan Krzysztof, Poczet biskupów lubelskich, http://www.bu.kul.pl/art_11485. html (dostęp: 01.12.2019).

Winiarz Adam, Szkolnictwo Księstwa Warszawskiego i Królestwa Polskiego (1807-1831), Lublin 2012.

Ziółek Jan, Patriotyczna postawa duchowieństwa w czasie powstania 1830-1831 roku, „Roczniki Humanistyczne”, 28 (1980) z. 2, s. 79-103. 


\title{
AN INVENTORY OF THE BOOK COLLECTION BELONGING TO THE BISHOP OF THE LUBLIN DIOCESE, MATEUSZ WOJAKOWSKI (1775-1845) IN THE LIGHT OF NOTARIAL RECORDS
}

\begin{abstract}
The article presents an inventory of the book collection owned by the bishop of the Lublin diocese, Mateusz Wojakowski (1775-1845). The aim of the article is to reconstruct the book collection, i.e., to make the edition of the inventory available to recipients along with an initial analysis of the library's content. The inventory of the book collection can be found in a notarial register from 1845 , which is part of ,Records of Seraph Konwicki, a notary of the city of Lublin" kept in the State Archives in Lublin. In the source text, editing principles were applied in accordance with the Publishing Instructions for historical sources from the 16th to 19th century. Additionally, bibliographic data was supplemented and enriched, because the source information about the copies of books owned by the clergyman was incomplete, as they were originally used only for inheritance purposes. The full title, author's name, place and year of publication were established on the basis of available bibliographies and library catalogues. The findings will allow for a more comprehensive analysis of the contents of the bishop's home library. The inventory of 220 items lists a total of 255 titles of works in 296 volumes. The collected books were mainly in Polish, and additionally also in Latin, French and German. The clergyman's home book collection was of universal character. It included books and magazines in various fields: general, law, education, philosophy, history, geography, dictionaries, natural and applied sciences, and belles-lettres. Religious prints constituted an important part, including liturgical books, sermons, catechisms, prayer books, the Bible, and meditations. The inventory of the book collection of Bishop Wojakowski - a figure distinguished not only in the field of pastoral but also civic activity - has remained unknown and unused in literature so far. It is also an example inventory of a 19th-century book collection belonging to a clergyman.
\end{abstract}

Keywords: book collection; bishop Mateusz Wojakowski; clergy; notarial records; inventory; 19th century 